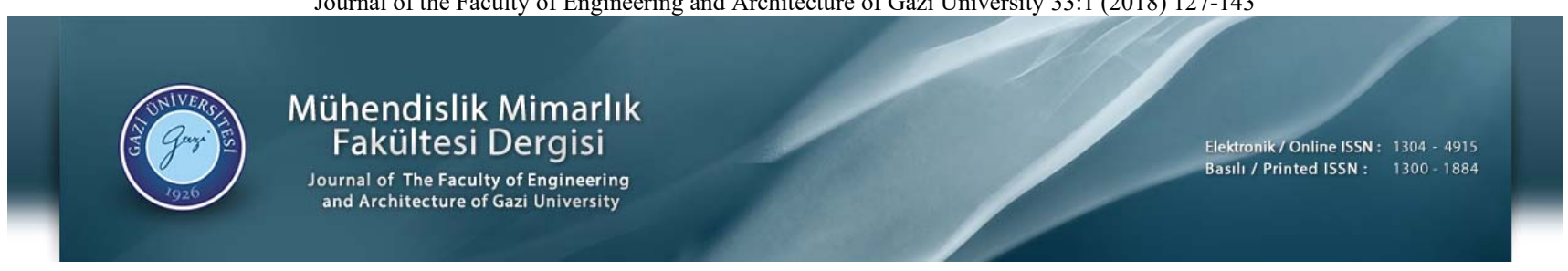

\title{
Ti6A14v toz alaşımı kullanılarak SLS ile üretilen geçişli (değişken) gözenekli numunelerin mekanik özelliklerinin incelenmesi
}

\author{
Mehmet Cengiz Kayacan ${ }^{1 *(D)}$, Yunus Emre Delikanlı² ${ }^{(D)}$ Burhan Duman ${ }^{3}$ (D), Koray Özsoy² \\ 'Süleyman Demirel Üniversitesi, Makine Mühendisliği Bölümü, Çünür, Isparta, 32260, Türkiye \\ ${ }^{2}$ Süleyman Demirel Üniversitesi, Senirkent Meslek Yüksekokulu, Senirkent, Isparta, 32600, Türkiye \\ ${ }^{3}$ Süleyman Demirel Üniversitesi, Uluborlu Selahattin Karasoy Meslek Yüksekokulu, Uluborlu, Isparta, 32650, Türkiye
}

Ö N E Ç I K A N L A R

- Titanyum gözenekli implant

- İmplantın dış yüzeyinin (kabuk bölgesi) yarım küresel mikro gözenekten (kontrollü gözenekten) oluşturulması

- Eklemeli imalatta farklı tarama stratejileri ve farklı imalat parametreleri kullanımının mekanik özelliklere etkisi

Makale Bilgileri

Geliş: 30.09.2016

Kabul: 23.12.2016

DOI:

10.17341/gazimmfd.406786

Anahtar Kelimeler:

İmplant,

eklemeli imalat,

kemik,

doğrudan metal lazer

sinterleme,

gözenekli yapı

\section{ÖZET}

Günümüzde eklemeli imalat teknolojilerinin gelișmesine bağlı olarak, bu imalat yönteminde kullanılabilen malzeme çeşidi de oldukça artmış ve titanyum alaşımları da bu alanda yerini almıştır. Eklemeli imalat teknolojisi sayesinde geleneksel imalat yöntemleri ile üretimi mümkün olmayan geometriler oluşturularak, protez ve implantlarda "kișiye özel"lik kavramı doğmus ve hastanın kusurlu bölgesine daha uyumlu, aynı zamanda daha hafif implantların üretilebilmesi mümkün hale gelmiştir. Geleneksel yöntemlerle imal edilen metalik implantların rijitliklerinin içine ya da üzerine yerleştirildiği kemiğe göre daha yüksek olması, zaman içerisinde implant cevresindeki kemik dokuda tahribat olusturabilmektedir. Kemiklere yerlestirilecek implantların elastikiyetlerinin kemiğe yakın olması beklenmektedir. Eklemeli imalat teknolojileri sayesinde implantların iç bölgesinde kontrollü geçişli gözenekli (poroz) mikro yapılar oluşturulabilmektedir. Böylece, kullanım yerinde yeterince dayanıkl, rijitliği düşürülmüss, hafif implantlar üretilebilmekte ve gözeneklendirilmiş yüzeyleri sayesinde kemik doku gelişimini artırarak kullanım yerindeki kemikle iyi bir osseointegrasyon sağlamaktadırlar. Bu çalışmada, seçici lazer sinterleme yöntemiyle farklı parametrelerde üretilmiş deney numunelerinin mekanik özellikleri incelenmiştir. Numunelerin dış yüzeyi kontrollü gözenekli (yarım küresel/eliptik vs.) geometri ile pürüzlendirilmiş ve iç bölgesi ise geçişli (değişken) gözenekli şekilde tasarlanmıştır. Çekme dayanımları, basma dayanımları, darbe dirençleri ve sertlikleri ölçülerek en iyi parametre/parametreler belirlenmiștir. Farklı tarama stratejileri, farklı parametreler kullanılarak elde edilen sonuçlar literatürle kıyaslanmıştır.

\section{Examining of mechanical properties of transitive (variable) porous specimens produced by SLS using ti6A14v alloy powder}

\section{H I G H L I G H T S}

- $\quad$ Porous implant made of titanium

- Forming the outer surface of the implant (shell region) from semi-spherical micropores (controlled porous)

- $\quad$ Effects of using different scanning strategies and different manufacturing parameters in additive manufacturing on mechanical properties

Article Info

Received: 30.09 .2016

Accepted: 23.12 .2016

DOI:

10.17341/gazimmfd.406786

Keywords:

Implant,

Additive Manufacturing,

Bone,

Direct Metal Laser Sintering,

Porous Structure

\section{ABSTRACT}

Nowadays depending on improvement of additive manufacturing technologies, materials variety that can be used in this manufacturing method has been raised and titanium alloys also took part in this area. With the additive manufacturing technology, by creation of geometries whose production is not possible with conventional manufacturing methods, "personal implant" concept has arised and it has become possible to produce implants which are lighter and more compatible to the patient's defective area. Being higher of the rigidities of metallic implants produced by traditional manufacturing methods, according to the bones they were located in, may cause devastation on bone tissues around the implant in time. The elasticity of the implant to be implanted into the bone, is expected to be close to the bone. It can be created controlled transitive micro porous structures inside the implants thanks to additive manufacturing technologies. So, much more durable and light implants can be produced and they provide more osseointegration with the bone in located area by the help of their porous surfaces. In this study, mechanic properties of test specimens were examined which were produced by selective laser sintering using different parameters. Outer surfaces of the specimens have roughened with controlled porosity (semi spherical / elliptic geometry etc.) and inner region of the specimens were designed with transitive (variable) porosity. Tensile strenghts, compressive strenghts, impact resistances and hardnesses of the all specimens were measured and the best manufacturing parameter/parameters were determined. Results obtained from using different scanning strategies and different parameters were compared with literature 


\section{GIRIŞS (INTRODUCTION)}

Canlıların vücudunda meydana gelen hasarlardan dolayı doku veya organlar görevini yapamaz hale gelebilir. Hasar gören bölgeleri tekrar fonksiyonel hale getirmek için, ameliyat sürecinde zarar gören kemik yerine, gerçeğe yakın doku veya organın benzerleri imal edilir. Hasarlı doku veya organın işlevini yerine getirmek için imal edilen bu yapay cisimlere implant denilmektedir. Doğuştan gelen hastalıklar, kanser, travma, kaza vb. sebeplerle hastalarda meydana gelen kemik yapısı bozukluklarını tedavi etmek için kusurlu bölgelere implant yerleştirilmektedir [1]. İmplant malzemesinin seçiminde, kemiğin mekanik ve biyolojik özelliklerinin yanında implantasyonun yapılabilmesi için implantın uygulanacağ alınması gerekmektedir [2]. Çünkü implantlar, insan vücudunun değişik bölgelerinde farklı türde kuvvetlere maruz kalmaktadır. Walter [3], günlük aktiviteler sırasında kemiklerde yaklaşı $4 \mathrm{MPa}$, tendonlarda $40-80 \mathrm{MPa}$ değerinde gerilmeler oluştuğunu; normal yürüyüş sırasında ise, kalça kemiği üzerine yaklaşık $3 \mathrm{kN}$ yük etki ettiği ve bu yükün $100 \mathrm{~mm}^{2}$ kesite sahip bir kemikte yaklaşık $30 \mathrm{MPa}$ değerinde gerilme oluşturacağını belirtmiştir. Wang vd. tarafından yapılan çalışmada [4], yürüme esnasında kalça ekleminin, vücut ağırlığının (80 kg'lık bir vücut ağırlığının) 3,5 katına kadar yüklendiği deneysel olarak ölçülmüş olup, total kalça implantlarının eklem yerindeki sürtünme ile oluşan aşınmaya karşı da dirençli olması gerektiği vurgulanmıştır. Kafatası kemiğinin yapısı da genel olarak diğer kemik yapılarına benzemektedir. Ancak kafatası kemiği kalınlığı değişebilen yassı ve süngerimsi bir yapıda olup, iç ve dış tarafta kompakt kemik tabakalarıyla örtülüdür. $\mathrm{Bu}$ iki sert tabaka arasında gözenekli bir yap1 mevcuttur ve gözenek boşlukları ince hücresel tabaka (endosteum) ile örtülüdür [5].

İmplantların imalatında kullanılacak malzemenin sahip olması gereken özellikler, implantasyonun yapılacağı yere göre değişebilmektedir. Malzeme teknolojisinin gelişmesiyle birlikte vücut içerisine yerleştirilen implantlarda birçok farklı biyouyumlu malzeme kullanılabilmektedir. Wang vd. [4], İşoğlu vd. [6] ve
Schmoelz [7], bu malzemeleri; metaller, seramikler, polimerler ve kompozitler ana grupları altında toplamışlardır (Tablo 1). Bu siniflandirma, metal ve metal olmayan malzemeler olarak da yapılabilir [8]. Metalik biyomalzemeler; kaldırma, koşma, bükme ve çiğneme içeren aktiviteler gibi çevrimsel baskıların olduğu alanlarda kullanılmaktadır. Aşınmaya ve korozyona karşı direncin gerektiği yerlerde seramik malzemelerin kullanımı benimsenmiştir. Polimerik malzemeler, kararlılık ve esnekliğin gerektiği yerlerde kullanılmaktadır. Kompozit malzemeler ise; implantın sertlik derecesinin, temasta olduğu dokularla eşit olması gereken yerlerde ve yumuşak doku implantlarında kullanılırlar [9]. Metalik implantların dayanımı ve elastisite modülü, kemiğin dayanımından daha yüksektir [3, 10]. Metalik biyomalzemelerin elastisite modülleri yüksek (316L paslanmaz çelikte $200 \mathrm{GPa}$, titanyumda $110 \mathrm{GPa}$ ) seviyelerde iken, insan kemiğinde bu değer 10-15 $\mathrm{GPa}$ dolaylarındadır [11]. $\mathrm{Bu}$ mekanik uyumsuzluk, implantların yapısal olarak insan kemiğinden daha rijit olmasına sebep olmakta ve kemik dokusundaki gerilme dağılımını olumsuz yönde etkilemektedir. Bundan dolayı seçilen implant malzemesinin kullanım yerindeki kemik dokunun elastisite modülüne en yakın malzemeden seçilmesi ve o bölgede yeterli derecede rijitlik sağlaması gerekmektedir [7]. Bu bakımdan kullanım yerinde yeterince rijitlik sağladıklarından dolayı özellikle vücut içerisine yerleştirilen implantlarda metalik biyomalzemeler tercih edilmektedir. Tablo 2'de bazı metalik biyomalzemelerin kullanım yerleri avantaj ve dezavantajlarıyla birlikte verilmiştir. Bir implantın sünek ve dayanımlı olması amacı ile kullanılan metal malzemeler; paslanmaz çelik, kobaltkrom alaşımı veya titanyum alaşımlı malzemelerdir. Titanyum, paslanmaz çelikten daha pahalı olmasına rağmen yüksek mukavemeti, düşük ağırlık oran1, korozyon direncinin yüksek olması gibi üstün karakteristik özelliklerinin yanında uzun ömürlü olması sebebiyle daha çok tercih edilir [11]. Beklenen mekanik özelliklerin tümü hiçbir malzemede bir arada bulunmamaktadır. Düşük elastisite modülü ve yüksek dayanım gibi özellikler bile bazı malzemelerde karşılanamamaktadır. Bu nedenle herhangi bir implant için seçilecek olan malzemenin, implantın özel fonksiyonu için zorunlu gereksinimleri karşılayacak

Tablo 1. Biyomalzemelerin sinıflandırılmas1 (Classification of biomaterials)

\begin{tabular}{|c|c|c|c|c|}
\hline $\begin{array}{l}\text { Malzeme } \\
\text { Türü }\end{array}$ & Metal & Seramik & Polimer & Kompozit \\
\hline Avantaj & $\begin{array}{l}\text { Dayanımı yüksek } \\
\text { Sert } \\
\text { Sünek }\end{array}$ & $\begin{array}{l}\text { Biyouyumu } \\
\text { yüksek } \\
\text { Bası kuvvetlerine } \\
\text { dayanıklı }\end{array}$ & $\begin{array}{l}\text { Şekil vermesi kolay } \\
\text { Esnek }\end{array}$ & $\begin{array}{l}\text { Dayanımı yüksek } \\
\text { İhyitaca göre } \\
\text { hazırlanabilir }\end{array}$ \\
\hline Dezavantaj & $\begin{array}{l}\text { Korozyona } \\
\text { uğrayabilir } \\
\text { Ağır } \\
\text { İmalatı güç } \\
\text { (Geleneksel } \\
\text { yöntemler ile) }\end{array}$ & $\begin{array}{l}\text { Esnek değil } \\
\text { Kırılgan } \\
\text { Gerilme } \\
\text { dayanımı düşük }\end{array}$ & $\begin{array}{l}\text { Bozunabilir } \\
\text { Dayanımı düşük } \\
\text { Zamanla } \\
\text { deformasyona } \\
\text { uğrayabilir }\end{array}$ & İmalatı zor \\
\hline
\end{tabular}


Tablo 2. Metalik biyomalzemelerin kullanım alanları (Application Areas of Metallic Biomaterials)[12].

\begin{tabular}{|c|c|c|c|}
\hline Malzeme türü & Kullanım Yerleri & Avantajları & Dezavantajları \\
\hline CrCo alaşımları & $\begin{array}{l}\text { Diş implantları, } \\
\text { Kalça implantları, } \\
\text { Levha tipi tutturucular, } \\
\text { Ortopedik implantlar, } \\
\text { Eklem kafa bileşenleri }\end{array}$ & $\begin{array}{l}\text { Yüksek dayanım, } \\
\text { Yüksek korozyon direnci, } \\
\text { Yüksek aşınma direnci (çeliğe } \\
\text { göre), } \\
\text { Yüksek yorulma direnci, } \\
\text { Yüzey parlatılabilirliği, } \\
\text { Düşük Nikel oranı }\end{array}$ & $\begin{array}{l}\text { Sert bir metaldir, } \\
\text { İşlenmesi zordur, } \\
\text { Çok daha pahalıdır } \\
\text { (çeliğe göre) }\end{array}$ \\
\hline $\begin{array}{l}\text { Paslanmaz çelik } \\
(316 \mathrm{~L})\end{array}$ & $\begin{array}{l}\text { Kalça implantları } \\
\text { (femur), } \\
\text { Sabitleme ve yerleştirme } \\
\text { için pimler, } \\
\text { Plakalar ve vidalarda, } \\
\text { Kalp kapakçıklarında }\end{array}$ & $\begin{array}{l}\text { Yükssek dayanım, } \\
\text { Yüksek korozyon direnci, } \\
\text { Geliştirilmiş biyouyumluluk, } \\
\text { (Paslanmaz çeliklerin diğer } \\
\text { türleri ile karş1laştırıldıklarında), } \\
\text { Ucuz, } \\
\text { Kolay üretilebilir }\end{array}$ & $\begin{array}{l}\text { Alaşımındaki nikel, } \\
\text { bazı kişilerde } \\
\text { alerjiye sebep } \\
\text { olmaktadır }\end{array}$ \\
\hline $\begin{array}{l}\text { Titanyum } \\
\text { Alaşımları } \\
\text { (Ti6A14V) }\end{array}$ & $\begin{array}{l}\text { Eklemler, } \\
\text { Diş implantları, } \\
\text { Kafatası tabakası ve } \\
\text { kalça kemiği, } \\
\text { İmplantları(femur kök), } \\
\text { Geometrisi çok değişken } \\
\text { yerlerde }\end{array}$ & $\begin{array}{l}\text { Çok yüksek yüzey kaliteleri, } \\
\text { Mükemmel dayanım, } \\
\text { Çok iyi Biyouyumluluk, } \\
\text { Düşük yoğunluk, } \\
\text { Çok iyi korozyon direnci, } \\
\text { Yüksek yorulma direnci, } \\
\text { Hafif, } \\
\text { Kayma deformasyonuna } \\
\text { dayanıkl1, } \\
\text { Kontrol edilebilir gözeneklilik }\end{array}$ & $\begin{array}{l}\text { Pahalı olması, } \\
\text { Çekme dayanımı } \\
\text { kobalt ve çeliğe } \\
\text { göre daha azdır, } \\
\text { düşük sertliği } \\
\text { sebebiyle } \\
\text { aşınma direnci } \\
\text { yoktur }\end{array}$ \\
\hline
\end{tabular}

özelliklere sahip olması gerekmektedir [7]. İmplantların kullanımında biyomalzemelerin sadece bu mekanik özellikleri rol oynamamaktadır. Bunun yanı sıra, implantın karmaşık bir geometriye sahip olması durumunda tasarım ya da imalat kısıtları da düşünülmelidir.

İmplantlar geleneksel imalat yöntemleri ile standart şekil ve boyutlarda imal edilirler. Ancak insanlar farklı anatomik yapıya sahip olduklarından dolayı, standart boyutlardaki implantlar zaman zaman hastanın anatomik yapısına tam uymayabilir. Bununla birlikte son yıllarda gelişen teknolojiler sayesinde, kişiye özel şekil ve boyutlarda implantlar üretilebilmektedir [13]. Cerrahi operasyonlarda genel olarak standartlaştırılmış geometrik yapı boyut ve ölçülerdeki implantlar kullanılmaktadır. Standartlaştırılmış implantların takılması, hastaların yaşam kalitesinin istenilen düzeyde olmasına engel olmaktadır. İnsan kemiğinin içyapısı incelendiğinde kemiğin dış kısmının mikro gözenekli kabuk tabakasından, iç kısmının ise değişen gözenekli süngerimsi bir yapıdan oluştuğu görülmektedir. $\mathrm{Bu}$ nedenle, hastalarda anatomik yapıya tam uygun ve kişiye özel implantların imal edilmesine ihtiyaç duyulmaktadır. İmplantın hasta anatomisine tam uygun olması için kişiye özel tasarımın yanında, implantın dokularla uyumuna (osseointegrasyona) imkân veren gözenekli bir yapıya sahip olması da istenmektedir [14].

Günümüzde biyomedikal alanda kullanılan implantlar, eklemeli imalat yöntemleri ile kişiye özel olarak, geleneksel imalat yöntemlerine göre son derece hızlı ve yüksek boyutsal hassasiyetle imal edilebilmektedirler. Kişiye özel üretilen implantların mükemmel geometrik uyumu sayesinde, hastanın implant uygulandıktan sonraki iyileşme süreci ve şikâyetleri azalmaktadır. İhtiyaca bağlı olarak gelişen teknolojiyle birlikte implantlar da sürekli gelişmekte ve çeşitlenmekte; buna bağlı olarak da üretim yöntemleri çeşitlilik göstermektedir. Hastaya en uyumlu implantların en kısa sürede ve minimum maliyetle üretilebilmesi için sürekli üretim yöntemleri de geliştirilmektedir. Eklemeli imalat cihazlarının özellikle tıp alanındaki implant üretimi uygulamalarındaki kolaylıkları ve kazandırdığı yeniliklerle insan hayatını kolaylaştırması ve birebir uygulanabilirliği sayesinde kullanımı oldukça yaygınlaşmaktadır.

Eklemeli imalat yöntemlerinin avantajlarının başında, geleneksel imalat yöntemleri ile imal edilemeyen karmaşık geometrilere sahip parçaların bu yöntemler ile imal edilebilmesi gelmektedir. Bununla birlikte, destek malzemesi hariç hiç atık malzemenin olmayışı, tasarım esnekliği sağlaması ve tasarım sürecini hızlandırması gibi avantajlara da sahiptir [15].

Eklemeli imalatın; katmanların oluşturulma tekniği ve inşa hammaddesi olarak kullanılan malzemenin özelliğine göre farklı türleri mevcuttur. ASTM f2792 standardında eklemeli imalat yöntemleri kullandıkları teknolojiye göre; Ergiyik Yığma, Kontur İşleme, Seçici Lazer Sinterleme (SLS), Direk Metal Lazer Sinterleme, Seçici Lazer Ergitme (SLE), Elektron Işınlı Ergitme, Işıkla Kürleme, Malzeme Püskürtme, Bağlayıcı Püskürtme, Lazer İşleme ile Net Şekillendirme ve Elektron Işın Kaynağı olarak sınıflandırılmıştır [16]. Eklemeli imalat, Hızlı Prototipleme (Rapid Prototyping) teknolojisi şeklinde 90'l1 yılların başlarında gelişmeye başlamış ve üretimin her aşamasında 
giderek kullanımı artmıştır. Hızlı Prototipleme zaman içerisinde daha da geliştirilerek, metal tozlarından direkt parça (son ürün) imalatına geçilmiştir. Kalıp sanayi, uzay ve havacılık sanayi ve tıbbi malzeme imalatı gibi alanlarda SLS/SLE cihazlarından direkt olarak gerçek parçalarının üretimi birçok araştırmanın konusu olmaktadır. Bu yöntemle imal edilen parçalardaki mekanik özellikler, geleneksel yöntemlerle imal edilen parçalardaki mekanik özellikler ile hemen hemen aynı olmakta, hatta geçmektedir [17]. Çalışmada; SLS cihazında farklı imalat parametreleri ile üretilmiş ve implantlarda kullanılabilecek kontrollü geçişli gözenek yapının mekanik özellikleri incelenmiştir. Deney numuneleri, yarım küresel/eliptik gözeneklere sahip dış bölge ve diştan merkeze doğru gittikçe büyüyen geçişli (değişken) gözenek yapıya sahip iç bölgeden oluşmaktadır. Mikro gözenekler içerisinde gelişen hücreler ikinci bölge olan hücre gelişim kanalları aracılığı ile iç bölgeye doğru gelişim gösterecek şekilde modellenmiştir. İç bölgede ise hücre gelişim kanallarından içeriye doğru gelişim gösteren hücrelerin rahatça canlı yaşamını sağlayacak şekilde gözeneklilik sağlanmıştır. Bu yapı sayesinde kemik-implant ara yüzünde güçlü ve uzun ömürlü doku bağı oluşumunun sağlanması amaçlanmıştır.

\section{DENEYSEL METOT (EXPERIMENTAL METHOD)}

Vücut içerisindeki kullanım yerine bağlı olarak; implantlardan darbe dayanımı, yorulma dayanımı ve aşınma direnci gibi mekanik özelliklerinin yüksek olmas1 beklenmektedir. Dolayısıyla implant malzemelerinin yüksek biyouyumlu ve hafif olmaları gerekmektedir. Eklemeli imalat yöntemleri ile artık "kişiye özel" imalatın mümkün olmasıyla birlikte hastanın konforu ve yaşam kalitesi de malzeme özellikleriyle doğrudan ilişkili olmaktadır. Titanyum alaşımlarından biri olan Ti6Al4V alaşımı; hafif olması, korozyona dayanıklı bir alaşım olması ve yüksek spesifik mukavemete sahip olması gibi özelliklerinden dolayı medikal alanda oldukça sık kullanılmaktadır. CrCo alaşımları ve paslanmaz çelik gibi malzemelerle kıyaslandığında daha düşük elastisite modülüne sahip olması da bu malzemeyi tercih edilebilir kılmıştır. Çalışmada doku gelişimine imkân sağlayan geçişli gözenekli yapı oluşturulması hedeflenmiştir. Böylesi bir yapı karmaşık bir geometriye sahip olduğu için geleneksel imalat yöntemleri kullanılamamaktadır. Eklemeli imalat yöntemleri karmaşık geometrili yapıların imalatını mümkün kılması sebebiyle, seçici lazer sinterleme yöntemi tercih edilmiştir.

\subsection{Toz (Powder)}

Numunelerin malzemesi için; Ti6A14V alaşımının EOS firması tarafindan üretilen Ti64 ticari isimli metal tozu tercih edilmiştir. Kullanılan metal tozunun kimyasal bileşimi Tablo 3'de gösterilmiştir.

\subsection{Geçişli Gözenekli Tasarım(Transitive Porous Design)}

İnsan vücudunda; kemik dokularda bulunan kemik oluşumunu sağlayan öncü hücrelerin (osteoblast) yoğunluğu ve dizilimine göre süngerimsi (spongioz) ve kompakt (kortikal) olmak üzere iki farklı türde kemik yapısı bulunmaktadır. Kompakt kemik, boşluksuz fakat lamelli masif bir yapıya sahip olup, içinden kan damarları ve sinir hücrelerinin geçtiği kemik dokudur. Süngerimsi kemik ise aralarında boşluk olan fakat birbirine bağlı gözenekli (trabeküler) kanallardan oluşan bir yapıya sahiptir. Süngerimsi kemikte bulunan gözenekler ise kemiği çevreleyen kompakt kemiğe yakın bölgelerde küçük boyutlarda, iç bölgelerde ise biraz daha büyük boyutlardadır (Şekil 1).

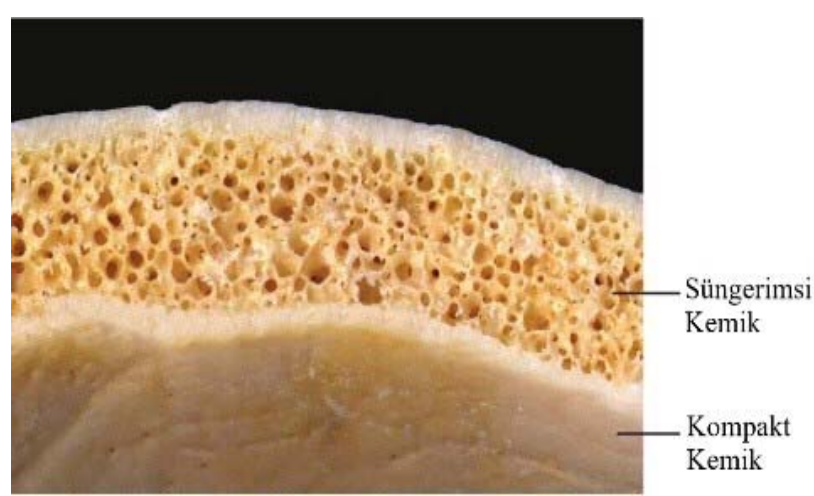

Şekil 1. Süngerimsi ve kompakt kemik doku (Cancellous and compact bone tissues) [19]

Eklemeli imalat yöntemleri ile karmaşık geometrili yapıların oluşturulabilmesi sayesinde implantların yeterli dayanımda ve daha hafif olmaları mümkün olmaktadır. Çalışmada; eklemeli imalatın bu büyük avantajı kullanılarak dış yüzeyi yarı küresel mikro gözenekler ile pürüzlendirilmiş, iç bölgesi ise çevreden merkeze doğru büyüyen geçişli (değişken) gözeneklere sahip, süngerimsi kemik doku benzeri bir yap1 tasarlanarak mekanik özellikleri incelenmiştir.

Tasarım; silindirik biçimde diş bölgeden (yarım küresel/eliptik gözenekler (oyuklar), hücre gelişim kanalları) ve iç bölgeden (dıştan merkeze doğru gittikçe büyüyen geçişli (değişken) gözenekli) oluşmaktadır. İki bölge birbirine bağlı tek bir parça olarak tasarlanmıştır (Şekil 2, Şekil 3). Dış bölge, mikro düzeyde yarım küresel/eliptik gözeneklerden oluşturulmuştur. İç bölgede ise; dış bölgedeki kanallarından içeriye doğru gelişim gösterecek doku hücrelerinin rahatça canlı yaşamını sağlayacak şekilde değişken/geçişli gözeneklilik sağlanmıştır. Geçişli gözenekli geometrinin yarı küresel geometriye sahip dış yüzeyi SolidWorks ${ }^{\circledR}$ yazılımında, geçişli gözenekli yapıya sahip iç bölgesi ise Netfabb® yazılımında modellenmiştir.

Tablo 3. Ti6Al4V metal tozu alaşımı kimyasal bileşimi (Chemical composition of Ti6Al4V metal powder alloy)[18]

\begin{tabular}{lllllllll}
\hline $\begin{array}{l}\text { Alaşım } \\
\text { Elementi }\end{array}$ & Al & $\mathrm{V}$ & $\mathrm{O}$ & $\mathrm{N}$ & $\mathrm{C}$ & $\mathrm{H}$ & $\mathrm{Fe}$ & $\mathrm{Ti}$ \\
\hline \%Ağırlık & $5,5-6,75$ & $3,5-4,5$ & $<2000 \mathrm{ppm}$ & $<500 \mathrm{ppm}$ & $<800 \mathrm{ppm}$ & $<150 \mathrm{ppm}$ & $<3000 \mathrm{ppm}$ & Kalan \\
\hline
\end{tabular}




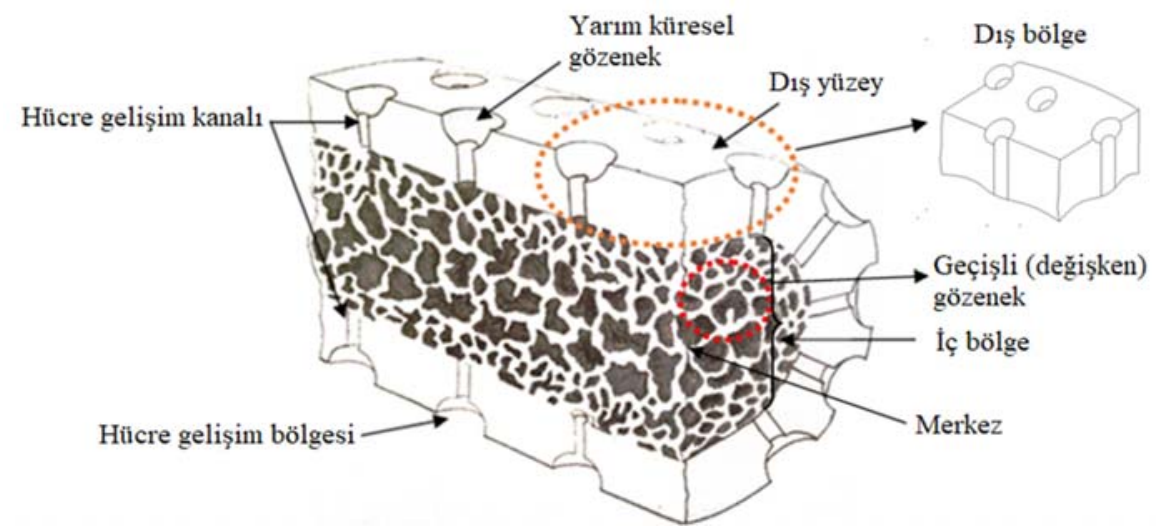

Şekil 2. Geçişli gözenekli oluşturulan yapının kesit görünümü (Section view of the transitive porous structure)

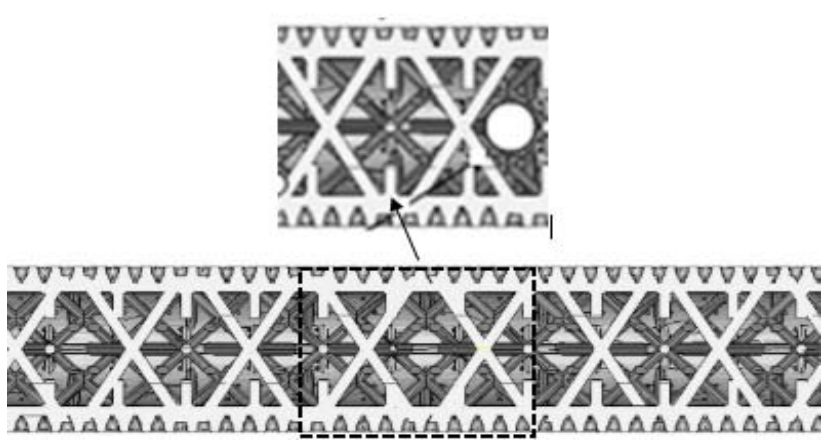

Şekil 3. Geçişli gözenekli yapının boyuna kesit görünümü (Longitudinal section of the transitive porous structure)

İç bölgenin gözeneklendirilmesi için kullanılacak yapı elemanlarına karar verebilmek amacıyla dört farklı türde gözenek türü belirlenmiştir. Bunlar; oktagonal, KRZ, balpeteği ve FEM gözenek türleridir (Şekil 4). Dış yüzeyi yarı küresel gözenekli olacak şekilde TS EN ISO 6892-1 standardındaki çekme numuneleri üretilerek elastisite modülleri ölçülmüş ve tam dolu numune ile karşılaştırılmıştır. Çekme numunelerinin imalatında EOS "Direct Part" parametresi kullanılmıştır. Şekil 5'de dört faklı gözenek türünün kullanıldığı çekme numunelerinin enine kesitleri, Şekil 6'da ise bu numunelerin çekme testi öncesi ve test sonrası fotoğrafları görülmektedir. KRZ gözenek türünün düşük elastisite modülüne sahip olmasından dolayı, çalışmada KRZ gözenek türünün kullanılmasına karar verilmiştir. Tablo 4'de farklı gözenek türlerinin kullanıldığı çekme numunelerinden elde edilen elastisite modülleri verilmiştir.

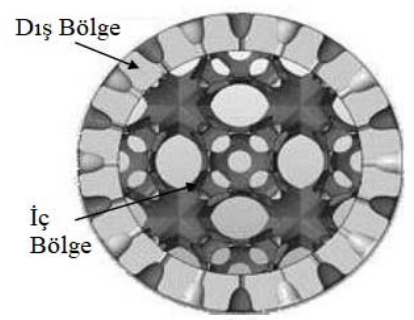

(a)

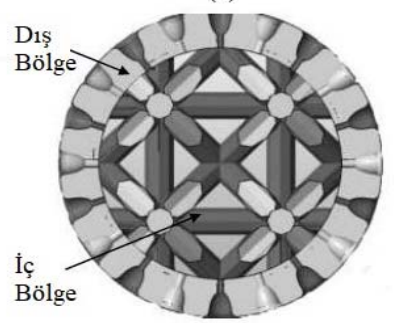

(c)

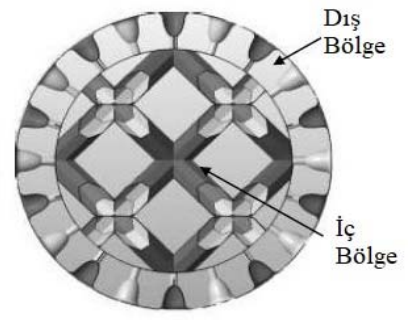

(b)

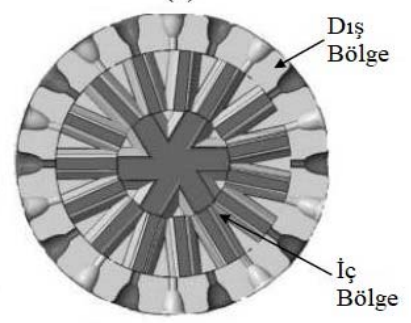

(d)
Şekil 5. Tasarlanan farklı gözenek türlerinin kullanıldığı çekme numunelerinin enine kesitleri a) FEM b) Oktagonal c) KRZ d) Balpeteği (Cross-sections of the different porous type tensile specimens a) FEM b) Octogonal c) KRZ d) Honeycomb)

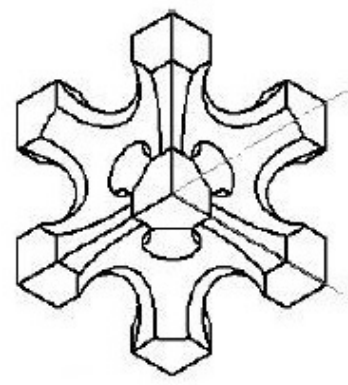

(a)

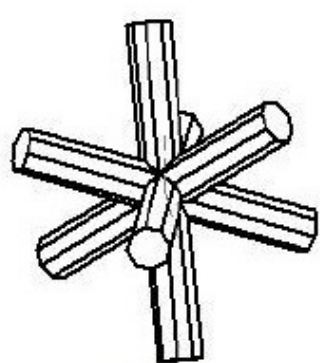

(b)

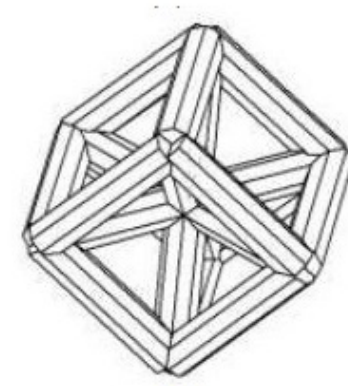

(c)

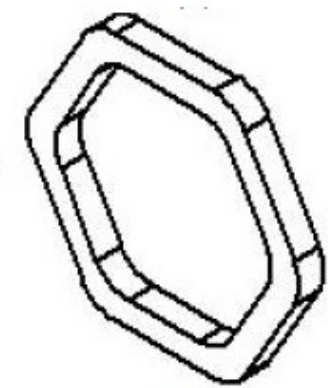

(d)

Şekil 4. Rijitliği en düşük gözenek yapıyı belirlemek üzere seçilen dört farklı birim gözenek yapı a) FEM b)Oktagonal c) KRZ d) Balpeteği (Four different unit cells, selected for determine the structure which has the lowest rigidity a)FEM b) Octagonal c) KRZ d) Honeycomb) 


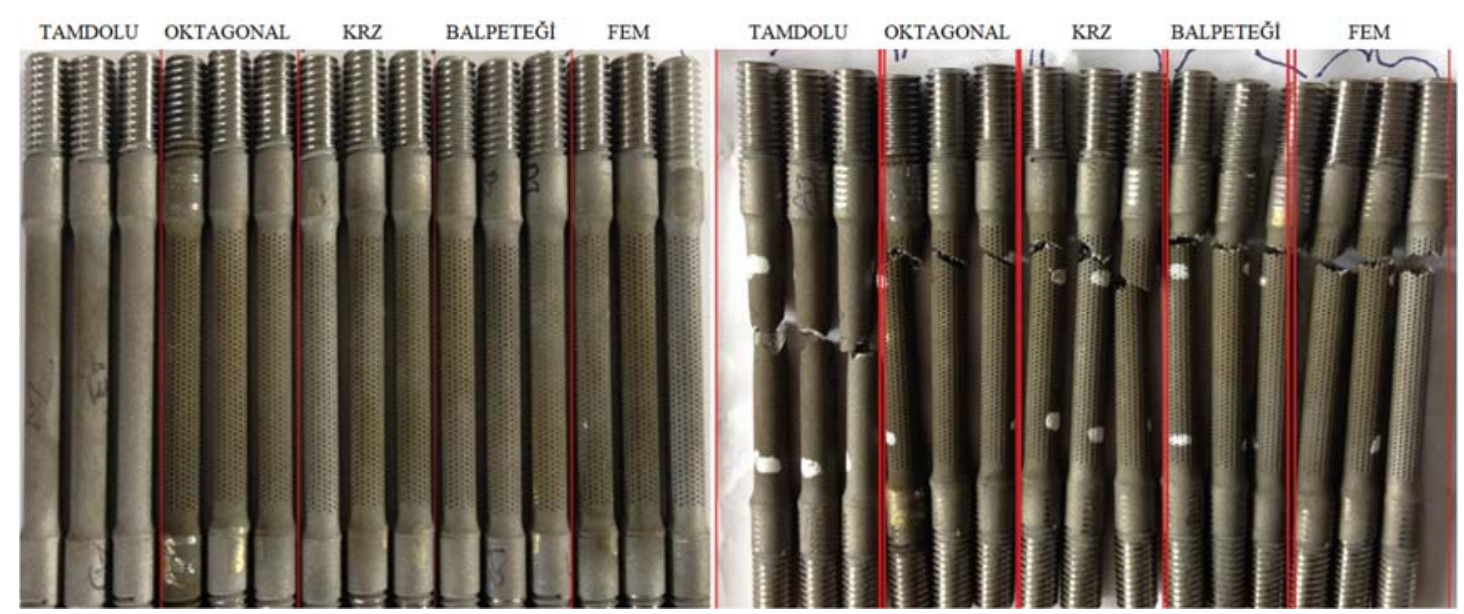

Şekil 6. Farklı gözenek türleri kullanılarak imal edilen çekme numunelerinin çekme testi öncesi ve sonrası fotoğrafları (Photographs of tensile specimens made by using different types of porous scaffolds before and after the tensile test)

Yukarıda bahsedilen geçişli gözenekli yapı kullanılarak, farklı imalat parametrelerinde ve yeterli sayıda çekme, basma ve çentik darbe numuneleri imal edilmiştir. Üretilen mekanik deney numuneleri Şekil 7, Şekil 8 ve Şekil 9'da görülmektedir.

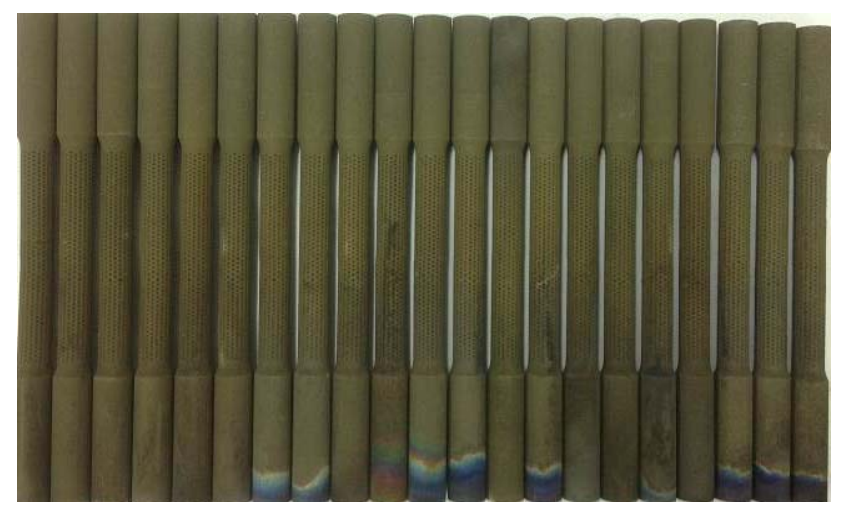

Şekil 7. KRZ gözenek yapısına sahip ve farklı imalat parametreleri ile üretilen çekme numuneleri (Tensile specimens with KRZ type porous scaffold and produced with different manufacturing parameters)

Çekme ve basma numuneleri SHIMADZU marka üniversal maksimum $100 \mathrm{kN}$ yük kapasite değerine sahip çekmebasma deney cihazı ile test edilmiştir. Çekme deneyleri oda sıcaklığında TS EN ISO 6892-1' e göre, basma deneyleri ise oda sıcaklığında ve TS 206'a göre yapılmıştır. Çentik darbe numuneleri SHIMADZU marka üniversal çentikli charpy darbe deney cihazında test edilmiştir. Deneyler oda sıcaklığında TS EN ISO 148-1 V'ye göre yapılmıştır. Mikro sertlik deney numuneleri, darbe numunelerinin uç kısımlarından $5 \mathrm{~mm}$ tel erozyon cihazında kesilerek hazırlanmıştır. Numuneler bakalite alınarak; zımparalanmış ve parlatılmış yüzeylerden ölçüm yapılmıştır. Mikro sertlik ölçümü, SHIMADZU marka mikro sertlik cihazında Vickers ölçümüne göre, 10 saniye süre boyunca 50 gr yük altında yapılmıştır. Şekil 10'da bakalite alınmış ve parlatılıış mikro sertlik deney numuneleri görülmektedir.

\subsection{Imalat Parametreleri ve Sinterleme Cihazı (Manufacturing Parameters and Sintering Device)}

Eklemeli imalatın doğası gereği parçanın arakesitleri katman birleştirilerek cismin son hali oluş̧urulur. Metal tozunun kullanıldığı seçici lazer ergitme ve seçici lazer sinterleme gibi eklemeli imalat yöntemlerinde, geometrinin ara kesitini birleştirmek için lazer ışığından elde edilen 1sı kullanılır. Dolayısıyla kullanılan lazerin gücü, parça arakesitinde odaklanan lazer ışınının çapı (lazer ışın çapı), lazerin parça arakesitinde nasıl hareket ettiği (tarama stratejisi), hızı ve hareket ederken geçtiği yollar arası mesafesi (tarama mesafesi) gibi faktörler, imalatı yapılan parçanın mekanik özelliklerini oldukça etkiler. Adı geçen faktörler imalat parametreleri olarak anılmaktadır. Literatürde en etkili işlem parametresi olarak, enerji yoğunluğu belirtilmektedir [20, 21]. İmalatta etkin parametreler olan, lazer gücü, lazer hızı ve lazer tarama mesafesinin bileşimi olan enerji yoğunluğu ile parçaların mekanik özellikleri ilişskilendirilebilir (Eş. 1). $\mathrm{Bu}$ parametrelerin çeşitli kombinasyonlarının kullanılması ile aynı alaşım tozundan farklı mekanik özelliklere sahip parça imalatı yapılabilmektedir.

$E=P /(v \cdot h)$

Eş. 1'de "E”, enerji yoğunluğunu, "P", lazer gücünü, “v", tarama hızını ve " $h$ ", tarama mesafesini ifade etmektedir. Burada lazer gücünün birimi $\mathrm{W}$, tarama hızı birimi $\mathrm{mm} / \mathrm{sn}$ ve tarama mesafesi birimi de $\mathrm{mm}$ cinsinden olursa, elde edilen enerji yoğunluğu birimi $\mathrm{J} / \mathrm{mm}^{2}$ olacaktır. Dolayısıyla enerji yoğunluğu, birim alan başına lazerin uyguladığ enerji olarak da tarif edilebilir. SLS/SLE süreci ile üretilen bir ürünün başarısı, sinterleme/ergitme olgusunu ve işlem için gerekli enerji yoğunluğunun miktarını etkileyen parametrelerin tam bir kontrolünü ve optimizasyonunu gerektirmektedir. $\mathrm{Bu}$ nedenle, çeşitli toz malzemeler kullanılarak işlem parametrelerini en iyilemeye yönelik birçok çalışma yapılmıştır $[22,23]$. İmalatı yapılan parçaların mekanik özelliklerinde, enerji yoğunluğunun yanında, tarama stratejisinin de büyük payı vardır [24]. Çalışmada, ızgara tarama ve ada tarama olmak üzere farklı imalat 


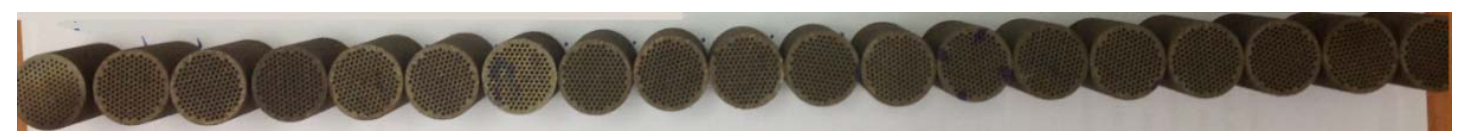

Şekil 8. KRZ gözenek yapısına sahip ve farklı imalat parametreleri ile üretilen basma numuneleri (Compression test specimens with KRZ type porous scaffold and produced with different manufacturing parameters)

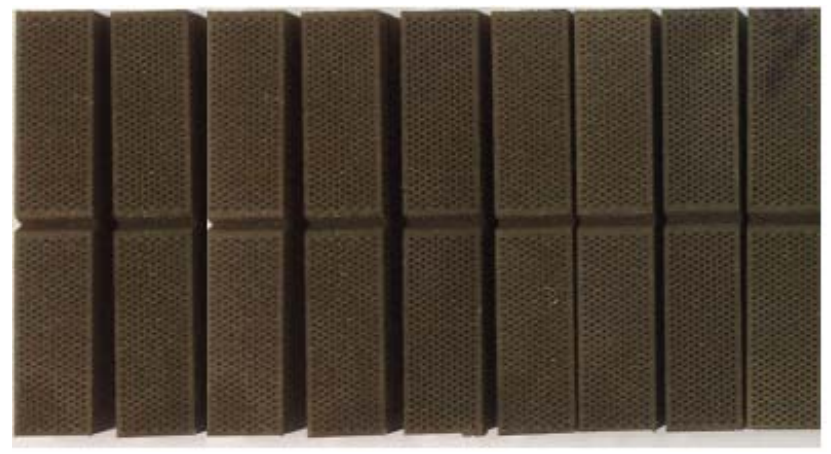

Şekil 9. KRZ gözenek yapısına sahip ve farklı imalat parametreleri ile üretilen çentik darbe numuneleri (Impact test specimens with KRZ type porous scaffold and produced with different manufacturing parameters)

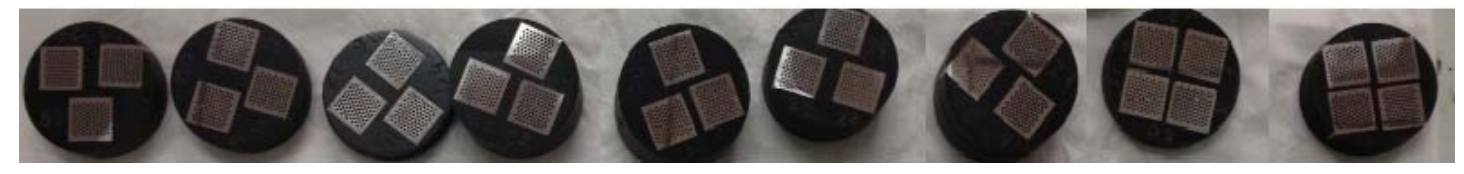

Şekil 10. Mikro sertlik deney numuneleri (Micro hardness test specimens)

parametrelerine sahip iki farklı tarama stratejisi kullanılmıştır. Izgara tarama stratejisinde; lazer, parça arakesitini belirlenen lazer gücü, lazer hızı ve tarama mesafelerinde $\mathrm{x}$ ve $\mathrm{y}$ ekseninde olmak üzere iki kere sinterlemektedir. Önce x ekseninde, daha sonra aynı katmanı y ekseninde sinterler. Şekil 11'de 1zgara tarama stratejisi görülmektedir.

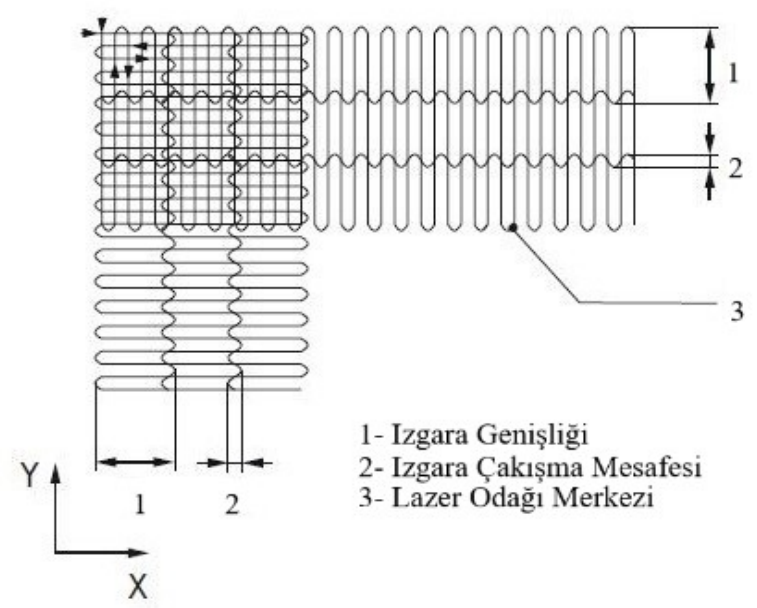

Şekil 11. Izgara tarama stratejisi [25]

(Grid type scanning strategy)

Ada tarama stratejisi; parça arakesitinde bulunan kare bölgelerden ve bu bölgeler arasında kalan boşlukların belirli bir sıra ile sinterlenmesidir. Öncelikle tüm kare bölgeler belirlenen lazer gücü, lazer hızı ve tarama mesafesinde belirlenen yönde (x ya da y ekseninde) rastgele sinterlenir.
Kare bölgelerin rastgele sinterlenmesinin sebebi, lazerin parça arakesitinde oluşturduğu 1sıyı yaymak ve böylece parça içerisinde oluşacak termal gerilmeleri azaltmaktır. Daha sonra kare bölgeler arasındaki boşluklar sinterlenir. Bir arakesit sinterlendikten sonra sinterleme doğrultusu $67^{\circ}$ saat yönünün tersine döndürülerek bir sonraki katman sinterlenir. Şekil 12'de ada tarama stratejisi görülmektedir.

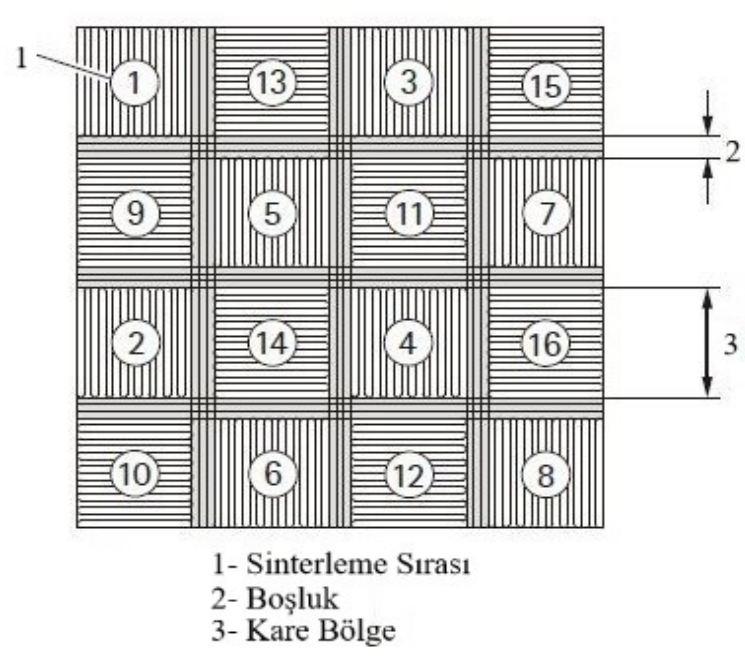

Şekil 12. Ada tarama stratejisi [25]

(Chess-rod type scanning strategy)

Yeterli dayanıma sahip ve malzemeden beklenen mekanik özellikleri sağlayacak şekilde imalat parametrelerin belirlenmesi oldukça önemlidir. Çalışmada EOS firmasının imalat parametreleri referans alınarak 18 adet imalat 
parametresi belirlenmiş ve mekanik deney numuneleri bu parametreler ile üretilmiştir. Tablo 5'de mekanik deney numunelerinin imalatında kullanılan parametreler görülmektedir. Mekanik deney numunelerinin tümü EOS firmasının M280 lazer sinterleme cihazında imal edilmiştir.

Numunelerin imalatında kullanılan Ti6A14V alaşımının toz tane boyutları 30-50 $\mu \mathrm{m}$ arasındadır. İmalat esnasında parça içerisinde oluşabilecek termal gerilmeleri azaltmak amaciyla imalat tablası yaklaşık $40^{\circ} \mathrm{C}$ 'ye 1 sitılmıştır. İmalat sonunda tüm numunelere $600^{\circ} \mathrm{C}$ sicaklıkta 3 saat süre ile gerilim giderme tav1 uygulanmıştır. Isıl işlem sonrasında tüm numuneler oda sicaklığında soğumaya bırakılmıştır. Üretilen numuneler imalat platformundan tel erozyon cihazı ile kesilerek ayrılmıştır.

\section{SONUÇLAR VE TARTIŞMALAR (RESULTS AND DISCUSSIONS)}

İmalat1 yapılan mekanik deney numune grupları, uygulanacak mekanik testlere göre adlandırılmıştır. Buna göre; çekme testi numune grubu "ÇD", basma testi numune grubu "BD", darbe testi numune grubu "DD" ve sertlik ölçümü numune grubu da "SD" harfi ile adlandırılmıştır. EOS firmasının referans alınan imalat parametreleri ile üretilen numune grubunda ise "EOS" kelimesi kullanılmıştır. Farklı işlem parametresi ile imal edilen çekme, basma ve darbe numunelerinin test sonuçları, aynı parametrelerin kullanıldığı üçer adet numunenin ortalamaları alınarak belirlenmiştir. Mikro sertlik ölçümleri birer numune üzerinden elde edilen üç değerin aritmetik ortalaması alınarak elde edilmiştir. Araştırma bulguları her mekanik deney için ayrı ayrı incelenmiş ve tablo halinde verilmiştir. Her mekanik deneyde elde edilen en yüksek ve en düşük ölçüm değerleri kalın punto kullanılarak vurgulanmıştır.

\section{1. Çekme Testi Sonuçları (Tensile Test Results)}

Çalışmadan elde edilen çekme testi sonuçları Tablo 6' da verilmiştir. Tablo 6 incelendiğinde; ada tarama stratejisinin kullanıldığ 1 numunelerin, 1zgara tarama stratejisinin kullanıldığı numunelere göre daha yüksek dayanım değerlerine sahip olduğu görülmektedir. Bunun nedeni; ada tarama stratejisinde lazerin rastgele karesel alanları sinterleyerek, arakesitte oluşan 1sının hızlı bir şekilde parçadan uzaklaştırılmasıdır. Ada tarama stratejisiyle üretilen gözenekli numunelerde elde edilen en yüksek dayanım değeri $343 \mathrm{MPa}$ ile ÇD9 numune grubunda elde edilmiştir. Izgara tarama stratejisiyle elde edilen en yüksek değer ise $346 \mathrm{MPa}$ ile ÇD16 numune grubunda gözlenmiştir. Izgara tarama stratejisiyle üretilen diğer numunelerin birçoğu, ada tarama stratejisiyle üretilenlere göre düşük olmasına karşın, ÇD16 numune grubunun çekme dayanımı ada tarama stratejisinin kullanıldığı numunelerden yüksek çıkmıştır. Lazer gücünün ÇD16 numune grubunda (170W), ÇD9 numune grubuna göre (190W) küçük olması, tarama hızının (ÇD16-1250mm/sn, ÇD9-1000mm/sn) yüksek, ve tarama mesafesinin ise (ÇD16- 0,07mm, ÇD9-0,09mm) az olması sebebiyle dayanım değeri (ÇD16- $346 \mathrm{MPa}$ ), ÇD9 numune grubundan (ÇD9 $343 \mathrm{MPa}$ ) büyük elde edilmiştir. Song vd. [26]; artan tarama hızının, çekme dayanımı ve akma dayanımını artırdığını belirtmiştir. Literatüre uygun olarak, ÇD16 ve ÇD9 numune grubu için dayanım değerinin tarama hızının artması ile arttığı sonucuna ulaşılmıştır. Tablo 6'daki numunelerin enerji yoğunlukları incelendiğinde ise; ada tarama stratejisiyle üretilen numunelerin enerji yoğunlukları arttıkça dayanım değerleri de artmaktadır. Ancak 1zgara tarama stratejisinde, enerji yoğunluğunun artmasıyla dayanım değerleri sürekli artı̧̧ göstermemekte, $1,94 \mathrm{~J} / \mathrm{mm}^{2}$ değerine sahip numune grubuna kadar artmakta, bu değerden sonra dayanım değerleri

Tablo 5. Mekanik deney numunelerinin imalatında kullanılan imalat parametreleri (Manufacturing parameters used for production of the mechanical test specimens)

\begin{tabular}{llllll}
\hline $\begin{array}{l}\text { Deney Grup } \\
\text { Numaras1 }\end{array}$ & $\begin{array}{l}\text { Tarama } \\
\text { Türü }\end{array}$ & $\begin{array}{l}\text { Lazer } \\
\text { Gücü }(\mathrm{W})\end{array}$ & $\begin{array}{l}\text { Tarama Hizı } \\
(\mathrm{mm} / \mathrm{sn})\end{array}$ & $\begin{array}{l}\text { Tarama } \\
\text { Mesafesi }(\mathrm{mm})\end{array}$ & $\begin{array}{l}\text { Enerji Yoğunluğu } \\
\left(\mathrm{J} / \mathrm{mm}^{2}\right)\end{array}$ \\
\hline 1 & Ada & 160 & 1500 & 0,11 & 0,97 \\
2 & Ada & 180 & 1500 & 0,11 & 1,09 \\
3 & Ada & 140 & 1000 & 0,09 & 1,56 \\
4 & Ada & 140 & 1250 & 0,07 & 1,60 \\
5 & Ada & 150 & 1000 & 0,09 & 1,67 \\
6 & Ada & 150 & 1250 & 0,07 & 1,71 \\
7 & Ada & 170 & 1000 & 0,09 & 1,89 \\
8 & Ada & 180 & 1000 & 0,09 & 2,00 \\
9 & Ada & 190 & 1000 & 0,09 & 2,11 \\
10 & Izgara & 140 & 1500 & 0,11 & 0,85 \\
11 & Izgara & 150 & 1500 & 0,11 & 1,93 \\
12 & Izgara & 170 & 1500 & 0,11 & 1,15 \\
13 & Izgara & 190 & 1500 & 0,11 & 1,78 \\
14 & Izgara & 160 & 1000 & 0,09 & 1,83 \\
15 & Izgara & 160 & 1250 & 0,07 & 1,94 \\
16 & Izgara & 170 & 1250 & 0,07 & 2,06 \\
17 & Izgara & 180 & 1250 & 0,07 & 2,17 \\
18 & Izgara & 190 & 1250 & 0,07 & \\
\hline
\end{tabular}


düşmektedir. Enerji yoğunluğunun yüksek olduğu parametrelerin kullanıldığ 1 her numunenin dayanım değerinin yüksek olması beklenemez. Çünkü enerji yoğunluğu; lazer gücü, tarama hızı ve tarama mesafesinin bir fonksiyonudur. Yadroitsev vd. [27], çalışmalarında, enerji yoğunluğunun ergimiş tozu kaynatacak ve buharlaştıracak seviyede çok yüksek olduğu parametrelerle imalat esnasında, parça arakesitindeki sinterlenmiş izlerde buhar geri tepme basıncının sebep olduğu bozulmalar gözlemlemişlerdir. Zira ÇD7 ve ÇD8 numune gruplarının enerji yoğunlukları sirasiyla $1,89 \mathrm{~J} / \mathrm{mm}^{2}$ ve $2 \mathrm{~J} / \mathrm{mm}^{2}$ 'dir ve bu numuneler, enerji yoğunluğu $1,36 \mathrm{~J} / \mathrm{mm}^{2}$ olan EOS parametrelerinin kullanıldığ1 numunelerle hemen hemen aynı dayanım değerlerine sahiptir. Sinterlenmiş izlerin yan yana kaynaşmasından katman, katmanların üst üste kaynaşmasından da parça oluştuğu bilinmektedir. Bozuk sinterlenmiş izler, katmanda ve dolayısı ile parçada istenilen nitelikte kaynaşma meydana getiremezler. Bu durum, imal edilen parçanın mekanik özelliklerini olumsuz yönde etkiler. Dolayısı ile imalat işleminde yüksek enerji yoğunluğu kullanımı parçanın dayanımını düşürmektedir. Kruth vd. [28] ve Gusarov vd. [29] çalışmalarında; yüksek lazer güçlerinin kullanıldığı parametrelerle imalat esnasında, parça arakesitinde uzun ince erime havuzlarının küresel şekilde parçalandığını gözlemlemişler ve parçaların dayanımı dayanımı düşüren bu durumu, "toplaşma etkisi”" olarak isimlendirmişlerdir.

Şekil 13 ve Şekil 14'de sırasıyla ada ve ızgara tarama stratejisiyle üretilen numunelerin çekme deneylerinden elde edilen grafikler verilmiştir. Ada ve 1zgara tarama stratejilerinin kullanıldığı ve en düşük dayanıma sahip numune grupları sırasıyla ÇD1 ve ÇD11 numune gruplarıdır. Her iki tarama stratejisinde de dayanım değerlerinin düşük olmasının sebebi, düşük lazer gücü, yüksek tarama hızı ve büyük tarama mesafesinin kullanılmasıdır. İmalat esnasında herhangi bir arakesitte, düşük lazer gücünün yüksek hızda ve büyük tarama mesafesinde hareket etmesi, o bölgeye az enerji bırakacağı anlamına gelmektedir. Bu da, daha düşük bir enerji yoğunluğuna sebep olmaktadır ve parçanın dayanımını düşürdüğü söylenebilir. Kompakt kemiğin çekme dayanımının 80-120 $\mathrm{MPa}$ [11] ve süngerimsi kemiğin çekme dayanımının $17 \mathrm{MPa}$ [11] olduğu göz önünde bulundurulduğunda, tüm numunelerin dayanım değerlerinde, süngerimsi kemik dokuların dayanım değerlerinden yüksek çekme dayanımı elde edilmiştir. Tablo 6 incelendiğinde; ÇD1, ÇD2, ÇD10 ve ÇD11 numune gruplarının ortalama çekme dayanımı değerlerinin kompakt kemik çekme dayanımından küçük olduğu görülmektedir. $\mathrm{Bu}$ numune grupları, ada ve 1zgara tarama stratejilerinde en düşük enerji yoğunluğunun kullanıldığı numune gruplarıdır. Düşük enerji yoğunluğu malzemenin mekanik özelliklerinin olumsuz etkilediği için bu numune gruplarında oldukça düşük değerler elde edilmiştir. Metalik implantların yerleştirildikleri kemik dokuya göre daha rijit olmasının sebeplerinden biri de, implant ile doku arasındaki bu dayanım farkıdır. Gözenekli numunelere göre daha büyük kesit alanlarına sahip olduklarından dolayı, en yüksek çekme dayanım değerleri tam dolu numunelerde elde edilmiştir.
Tam dolu numunelerin dayanım değerleri, geleneksel imalat yöntemleri (talaşlı imalat, hassas döküm vb.) ile üretilen tam dolu numunelerin dayanımlarıyla karşılaştırıldığında, ortalama basma gerilmelerinin birbirine yakın olduğu görülmektedir. Murr vd., [30] ile Puebla vd., [31]'nin çalışmalarında tam dolu ve gözenekli numunelerin çekme dayanımları 650-1200 MPa değerinde olup, çalışmaya benzer sonuçları içermektedir. Geçişli gözenekli numuneler arasındaki gerilme değerleri farklılıkları; farklı tarama stratejilerinden, farklı imalat parametrelerinden ve numuneler içindeki çentik etkilerinden kaynaklanmaktadır.

\subsection{Basma Testi Sonuçları (Compression Test Results)}

Ti6Al4V alaşımının basma ve çekme dayanımları birbirine yakındır [32]. Farklı imalat parametrelerine sahip basma numunelerinin ortalama basma dayanımı değerleri Tablo 7'de verilmiştir. Her iki tarama stratejisinde de en düşük enerji yoğunluğuna sahip numunelerin, en düşük basma gerilmesine sahip olduğu görülmektedir. Ada taramanın kullanıldığ1 ve enerji yoğunluğunun $0,97 \mathrm{~J} / \mathrm{mm}^{2}$ olduğu BD1 numune grubu $181 \mathrm{MPa}$, 1zgara taramanın kullanıldığı ve enerji yoğunluğunun $0,85 \mathrm{~J} / \mathrm{mm}^{2}$ olduğu BD10 numune grubu $145 \mathrm{MPa}$ ile en düşük basma gerilmesine sahiptir. Çekme testinde olduğu gibi; basma testlerinde de, en yüksek basma dayanımları tam dolu numunelerde elde edilmiştir. Bunun sebebi de, tam dolu numunelerin kesitlerinin boşluksuz yapıya sahip olmasıdır. Şekil 15 ve Şekil 16'da sırasiyla ada ve 1zgara tarama stratejisiyle üretilen numunelerin basma deneylerinden elde edilen grafikler verilmiştir. Ada tarama stratejisinin kullanıldığı BD7 numune grubunda en yüksek basma dayanımı $234 \mathrm{MPa}$, 1zgara tarama stratejisinin kullanıldığ 1 BD14 numune grubunda ise, en yüksek basma gerilmesi değeri $252 \mathrm{MPa}$ ölçülmüştür. BD14 numune grubunun basma dayanım değeri, EOS parametrelerinin kullanıldığı numunelerin basma dayanım değerlerinden daha yüksektir. Ada tarama stratejisinin kullanıldığı tüm numunelerin basma dayanım değerleri ise EOS parametreleri ile imal edilen numunelerden küçüktür. Bu sebeple, basma yükleri etkisi altında kalacak parçaların imalatı için ızgara tarama stratejisinin uygun olabileceği düşünülmektedir. Şekil 15'deki ada tarama stratejisinin kullanıldığ 1 numunelerin basma gerilmelerindeki değişimlerin, Şekil 16'daki grafikte 1zgara tarama stratejisinin kullanıldığı numunelerdeki değişimlerden daha az olduğu görülmektedir. Bunun sebebi parametrelerin enerji yoğunluklarındaki farklılıktır. Her iki tarama stratejisinin farklı parametrelerle kullanıldığı tüm numune gruplarının ortalama basma gerilmeleri 210 MPa'dır. Numune gruplarının ortalama basma gerilmeleri birbirine çok yakın olmasına karşın, tarama stratejisinin ve parametrelerin seçimine göre çok farklı değerlerde basma dayanımına sahip parçaların imalatı mümkündür. Basma deneyi sonucu elde edilen değerler incelendiğinde, her ne kadar 1zgara tarama stratejisinden elde edilen değerlerde gerilme değişimleri olsa da, en yüksek dayanım değeri bu tarama stratejisiyle elde edilmiştir. Ayrıca ızgara tarama stratejisinin kullanıldığ $\mathrm{BD} 13$ ve BD14 numune gruplarının basma gerilmelerinin, EOS numune gruplarının basma 
Kayacan ve ark. / Journal of the Faculty of Engineering and Architecture of Gazi University 33:1 (2018) 127-143

Tablo 6. Çekme numunelerinin imalat parametreleri ve ortalama çekme dayanımı değerleri (Manufacturing parameters and average tensile strenghts of the tensile specimens)

\begin{tabular}{|c|c|c|c|c|c|c|}
\hline Numune Grupları & $\begin{array}{l}\text { Tarama } \\
\text { Türü }\end{array}$ & $\begin{array}{l}\text { Lazer } \\
\text { gücü (W) }\end{array}$ & $\begin{array}{l}\text { Tarama Hiz1 } \\
(\mathrm{mm} / \mathrm{sn})\end{array}$ & $\begin{array}{l}\text { Tarama } \\
\text { Mesafesi } \\
(\mathrm{mm})\end{array}$ & $\begin{array}{l}\text { Enerji } \\
\text { Yoğunluğu } \\
\left(\mathrm{J} / \mathrm{mm}^{2}\right)\end{array}$ & $\begin{array}{l}\text { Ortalama } \\
\text { Çekme } \\
\text { Dayanımı } \\
(\mathrm{MPa})\end{array}$ \\
\hline ÇD1 & & 160 & 1500 & 0,11 & 0,97 & 151 \\
\hline ÇD2 & $\varangle$ & 180 & 1500 & 0,11 & 1,09 & 164 \\
\hline ÇD3 & $\sum$ & 140 & 1000 & 0,09 & 1,56 & 283 \\
\hline ÇD4 & 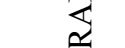 & 140 & 1250 & 0,07 & 1,60 & 280 \\
\hline ÇD5 & $\underset{E}{2}$ & 150 & 1000 & 0,09 & 1,67 & 298 \\
\hline ÇD6 & 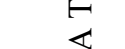 & 150 & 1250 & 0,07 & 1,71 & 295 \\
\hline ÇD7 & 穴 & 170 & 1000 & 0,09 & 1,89 & 335 \\
\hline ÇD8 & & 180 & 1000 & 0,09 & 2 & 334 \\
\hline ÇD9 & & 190 & 1000 & 0,09 & 2,11 & 343 \\
\hline ÇD10 & & 140 & 1500 & 0,11 & 0,85 & 184 \\
\hline ÇD11 & 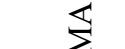 & 150 & 1500 & 0,11 & 0,91 & 177 \\
\hline ÇD12 & 衣 & 170 & 1500 & 0,11 & 1,03 & 214 \\
\hline ÇD13 & $\frac{2}{4}$ & 190 & 1500 & 0,11 & 1,15 & 240 \\
\hline ÇD14 & $F$ & 160 & 1000 & 0,09 & 1,78 & 279 \\
\hline ÇD15 & 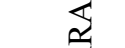 & 160 & 1250 & 0,07 & 1,83 & 304 \\
\hline ÇD16 & $\sum_{\pi}$ & 170 & 1250 & 0,07 & 1,94 & 346 \\
\hline ÇD17 & 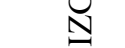 & 180 & 1250 & 0,07 & 2,06 & 328 \\
\hline ÇD18 & & 190 & 1250 & 0,07 & 2,17 & 291 \\
\hline ÇD-EOS & & 170 & 1250 & 0,1 & 1,36 & 335 \\
\hline TAM DOLU & & 170 & 1250 & 0,1 & 1,36 & 1100 \\
\hline $\begin{array}{l}\text { GELENEKSEL } \\
\text { İMALAT }\end{array}$ & & - & - & - & - & $960-1100$ \\
\hline
\end{tabular}

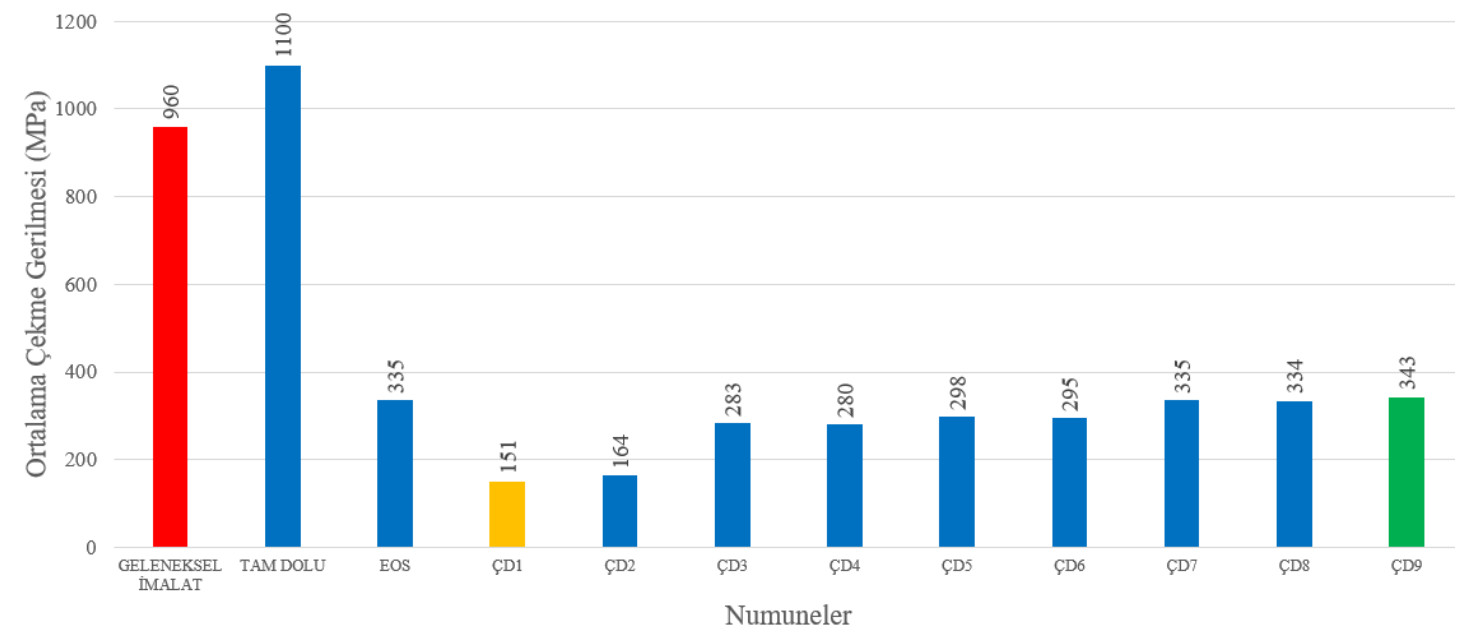

Şekil 13. Ada tarama stratejisi ile üretilen çekme numunelerin ortalama çekme gerilmeleri (Ultimate tensile strenghts of the specimens produced with chess-rod type scanning strategy)

gerilmelerine çok yakın olması, ızgara tarama stratejisinin basma gerilmesinin önemli olduğu parçalar için uygulanabilir olabileceğini düşündürmektedir.

\section{3. Çentik Darbe Deneyi Sonuçları (Charpy Test Results)}

Darbe deneyi malzemenin kırılana kadar yuttuğu enerjinin bir göstergesidir. Tam dolu bir numunenin kırılabilmesi için yutacağ ${ }_{1}$ enerji, gözenekli bir numuneden daha fazladır. $\mathrm{Bu}$ sebeple darbe deneyinde tam dolu numunelerin darbe dirençlerinin gözenekli numunelerin darbe dirençlerinden büyük olması beklenmektedir. Tablo 8 'de görüldüğü gibi en büyük darbe enerjileri $22 \mathrm{~J}$ değeri ile tam dolu numunelerde elde edilmiştir. Sünek malzemelerin darbe testi genellikle gerilme yığılmalarını belli bir bölgede yoğunlaştırmak için çentikli numuneler üzerinde yapılır. Çalışmadaki darbe numuneleri de çentikli olarak imal edilmiştir. Ancak hafifletilmiş geçişli gözeneğe sahip numunelerin iç bölgesindeki karmaşık geometrilerde de gerilme yı ̆̆ılmaları oluştuğundan dolayı, tüm gözenekli numunelerin darbe 
Kayacan ve ark. / Journal of the Faculty of Engineering and Architecture of Gazi University 33:1 (2018) 127-143

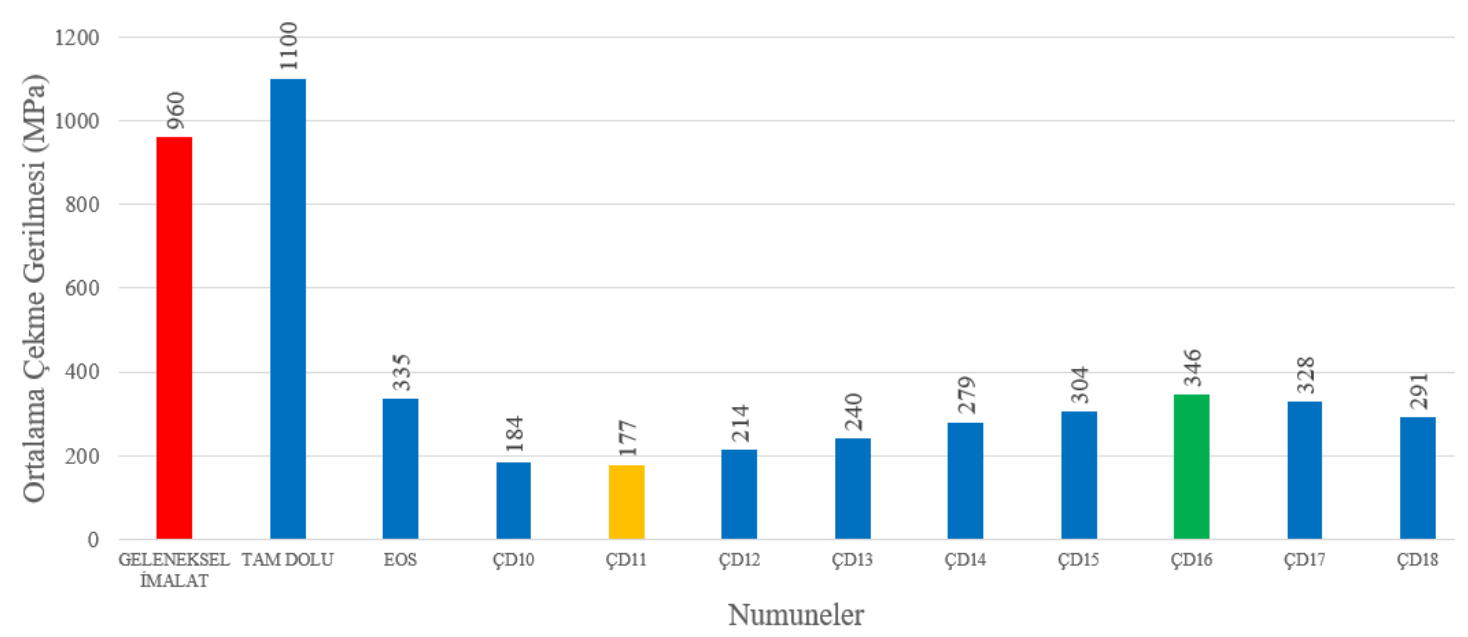

Şekil 14. Izgara tarama stratejisi ile üretilen çekme numunelerin ortalama çekme gerilmeleri (Ultimate tensile strenghts of the specimens produced with grid type scanning strategy)

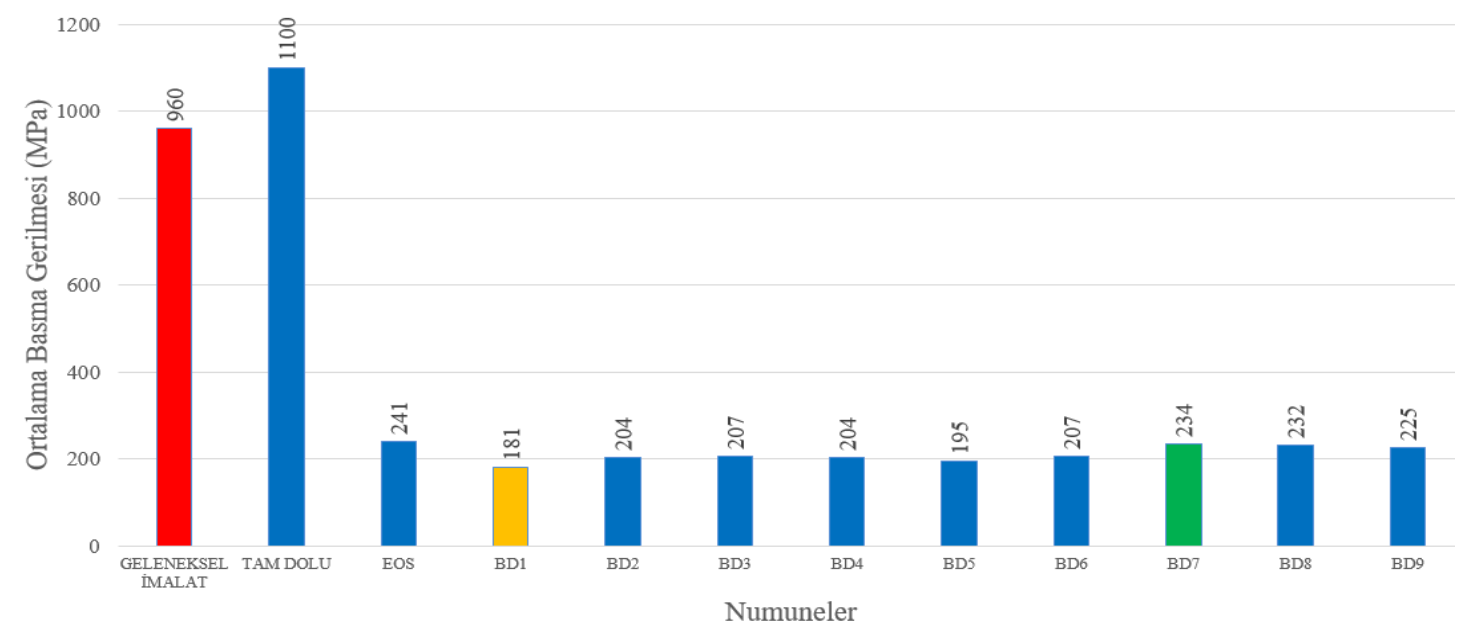

Şekil 15. Ada tarama stratejisi ile üretilen basma numunelerinin ortalama basma gerilmeleri (Average compressive strenghts of the specimens produced with chess-rod type scanning strategy)

enerjileri, tam dolu numunelerin darbe enerjilerinin ortalama $\% 58,4$ '̈ kadardır. Şekil $17^{\prime}$ de ada tarama stratejisiyle üretilen darbe numunelerinin test sonuçları verilmiştir. Ada tarama stratejisinin kullanıldığ 1 numune gruplarının darbe enerjileri birbirine çok yakındır. Ancak DD1 ve DD2 numune gruplarının darbe enerjileri diğer numune gruplarına göre oldukça küçük çıkmıştır. Bunun sebebinin, bu numune gruplarındaki parametrelerde kullanılan, düşük lazer gücünden kaynaklandığı düşünülmektedir. Ayrıca gözenekli numunelerin iç bölgeleri, karmaşık geometrili yapıya sahip olduğu için bazı dar açılı kısımlarda çentik etkisi oluşabilecek bölgeler bulunabilmektedir. Bu sebeple, darbe testi esnasında gerilme yığılmalarının çentikli bölgede yoğunlaşmayabilir. Numune içerisindeki karmaşık geometrili yapının herhangi bir bölgesinde oluşacak çatlak, plastik deformasyon, yırtık vb. süreksizlikler, test esnasında bu bölgelerde gerilme yı̆̆ılmalarının yoğunlaşmasına sebep olabilmektedir. Şekil 18'de 1zgara tarama stratejisiyle üretilen darbe numunelerinin test sonuçları verilmiştir. Şekil 18 incelendiğinde, en yüksek darbe enerjisinin, 15,61 J değeri ile 1zgara tarama stratejisinin kullanıldığı DD16 numune grubunda olduğu görülmektedir ve EOS numune grubunun darbe enerjisinden yüksektir. Bu değerden sonra 1zgara tarama stratejisinin kullanıldığ yoğunlukları arttıkça darbe enerjilerinde azalma görülmektedir. Ancak ada tarama stratejisinin kullanıldığ 1 numunelerin enerji yoğunlukları arttıkça darbe enerjileri de artmaktadır. Ada tarama stratejisinde elde edilen en yüksek değer, 12,56 J ile DD9 numune grubundadır. Her iki tarama stratejisinin kullanıldığı numune gruplarında en düşük değerler, en küçük enerji yoğunluğunun olduğu parametrelere sahip numunelerde gözlenmiştir. Ancak, ada tarama stratejisinin kullanıldığı numune gruplarının darbe enerjileri, DD1 ve DD2 numune grubu hariç, enerji yoğunluğuyla çok fazla değişim göstermemiştir. Darbe deneylerinden elde edilen sonuçlar incelendiğinde, 1zgara tarama stratejisinin parametrelerdeki enerji yoğunluğuna daha hassas olduğu anlaşılmaktadır. Ancak ada tarama stratejisinin kullanıldı ̆̆ numunelerin enerji yoğunlukları artsa bile, darbe enerjilerinde büyük farklılıklar olmamıştır. 
Kayacan ve ark. / Journal of the Faculty of Engineering and Architecture of Gazi University 33:1 (2018) 127-143

Tablo 7. Basma numunelerinin imalat parametreleri ve ortalama basma dayanımı değerleri (Manufacturing parameters and average compressive strenghts of the specimens)

\begin{tabular}{|c|c|c|c|c|c|c|}
\hline Numune Grupları & $\begin{array}{l}\text { Tarama } \\
\text { Türü }\end{array}$ & $\begin{array}{l}\text { Lazer } \\
\text { gücü } \\
(W)\end{array}$ & $\begin{array}{l}\text { Tarama Hiz1 } \\
(\mathrm{mm} / \mathrm{sn})\end{array}$ & $\begin{array}{l}\text { Tarama } \\
\text { Mesafesi } \\
(\mathrm{mm})\end{array}$ & $\begin{array}{l}\text { Enerji } \\
\text { Yoğunluğu } \\
(\mathrm{J} / \mathrm{mm} 2)\end{array}$ & $\begin{array}{l}\text { Ortalama } \\
\text { Basma } \\
\text { Gerilmesi } \\
(\mathrm{MPa})\end{array}$ \\
\hline BD1 & \multirow{9}{*}{ 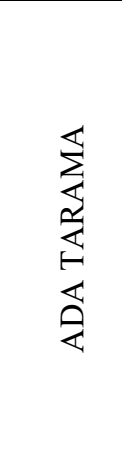 } & 160 & 1500 & 0,11 & 0,97 & 181 \\
\hline $\mathrm{BD} 2$ & & 180 & 1500 & 0,11 & 1,09 & 204 \\
\hline BD3 & & 140 & 1000 & 0,09 & 1,56 & 207 \\
\hline BD4 & & 140 & 1250 & 0,07 & 1,60 & 204 \\
\hline BD5 & & 150 & 1000 & 0,09 & 1,67 & 195 \\
\hline BD6 & & 150 & 1250 & 0,07 & 1,71 & 207 \\
\hline BD7 & & 170 & 1000 & 0,09 & 1,89 & 234 \\
\hline BD8 & & 180 & 1000 & 0,09 & 2 & 232 \\
\hline BD9 & & 190 & 1000 & 0,09 & 2,11 & 225 \\
\hline BD10 & \multirow{9}{*}{ 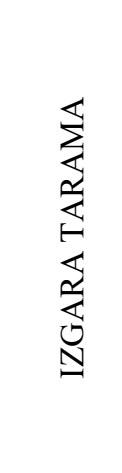 } & 140 & 1500 & 0,11 & 0,85 & 145 \\
\hline BD11 & & 150 & 1500 & 0,11 & 0,91 & 151 \\
\hline BD12 & & 170 & 1500 & 0,11 & 1,03 & 214 \\
\hline BD13 & & 190 & 1500 & 0,11 & 1,15 & 241 \\
\hline BD14 & & 160 & 1000 & 0,09 & 1,78 & 252 \\
\hline BD15 & & 160 & 1250 & 0,07 & 1,83 & 221 \\
\hline BD16 & & 170 & 1250 & 0,07 & 1,94 & 218 \\
\hline BD17 & & 180 & 1250 & 0,07 & 2,06 & 215 \\
\hline BD18 & & 190 & 1250 & 0,07 & 2,17 & 225 \\
\hline BD-EOS & & 170 & 1250 & 0,1 & 1,36 & 241 \\
\hline TAM DOLU & & 170 & 1250 & 0,1 & 1,36 & 1100 \\
\hline $\begin{array}{l}\text { GELENEKSEL } \\
\text { İMALAT }\end{array}$ & & - & - & - & - & $960-1100$ \\
\hline
\end{tabular}

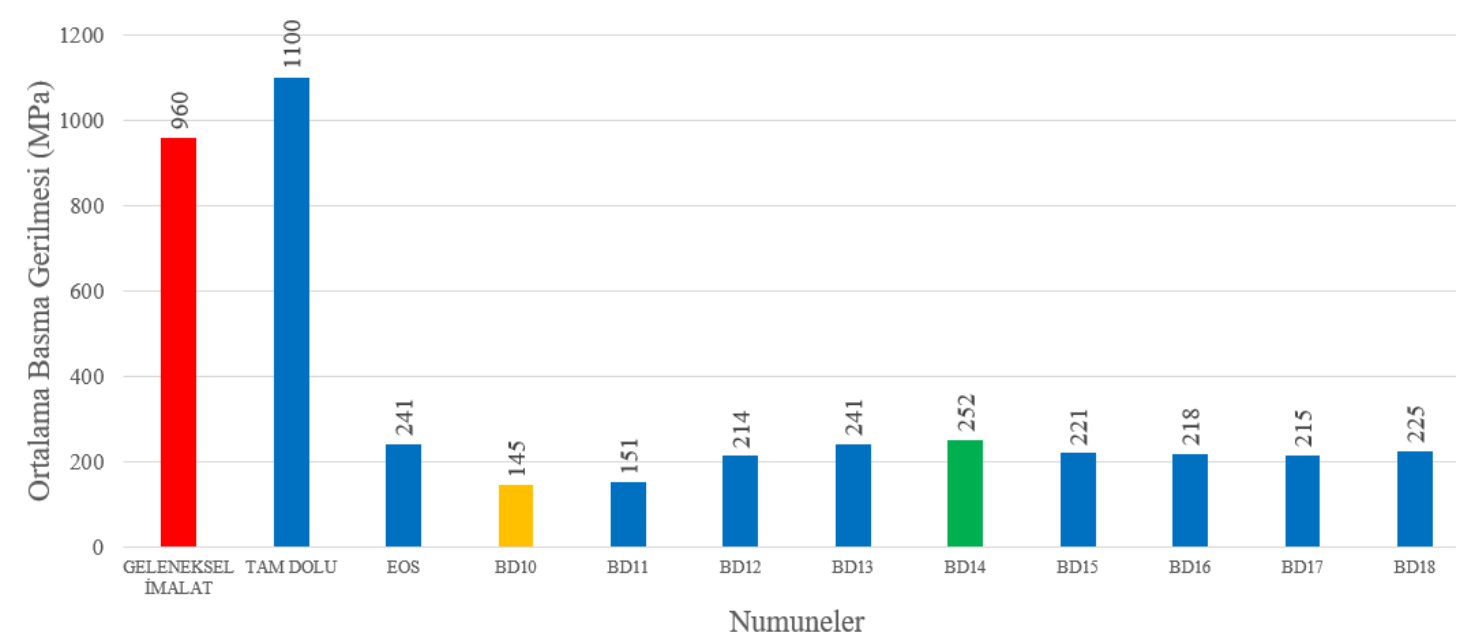

Şekil 16. Izgara tarama stratejisi ile üretilen basma numunelerinin ortalama basma gerilmeleri (Average compressive strenghts of the specimens produced with grid type scanning strategy) 
Kayacan ve ark. / Journal of the Faculty of Engineering and Architecture of Gazi University 33:1 (2018) 127-143

Tablo 8. Darbe numunelerinin imalat parametreleri ve ortalama darbe enerjileri (Manufacturing parameters and impact test results of the specimens)

\begin{tabular}{|c|c|c|c|c|c|c|}
\hline Numune Grupları & $\begin{array}{l}\text { Tarama } \\
\text { Türü }\end{array}$ & $\begin{array}{l}\text { Lazer } \\
\text { gücü } \\
(\mathrm{W}) \\
\end{array}$ & $\begin{array}{l}\text { Tarama Hiz1 } \\
(\mathrm{mm} / \mathrm{sn})\end{array}$ & $\begin{array}{l}\text { Tarama } \\
\text { Mesafesi } \\
(\mathrm{mm})\end{array}$ & $\begin{array}{l}\text { Enerji } \\
\text { Yoğunluğu } \\
\left(\mathrm{J} / \mathrm{mm}^{2}\right)\end{array}$ & $\begin{array}{l}\text { Ortalama } \\
\text { Darbe } \\
\text { Enerjisi }(\mathrm{J}) \\
\end{array}$ \\
\hline DD1 & \multirow{9}{*}{ 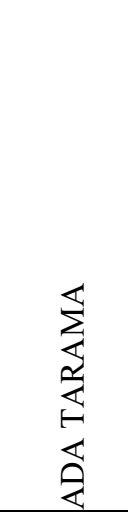 } & 160 & 1500 & 0,11 & 0,97 & 3,80 \\
\hline DD2 & & 180 & 1500 & 0,11 & 1,09 & 5,85 \\
\hline DD3 & & 140 & 1000 & 0,09 & 1,56 & 11,88 \\
\hline DD4 & & 140 & 1250 & 0,07 & 1,60 & 11,09 \\
\hline DD5 & & 150 & 1000 & 0,09 & 1,67 & 11,15 \\
\hline DD6 & & 150 & 1250 & 0,07 & 1,71 & 11,85 \\
\hline DD7 & & 170 & 1000 & 0,09 & 1,89 & 12,24 \\
\hline DD8 & & 180 & 1000 & 0,09 & 2 & 12,43 \\
\hline DD9 & & 190 & 1000 & 0,09 & 2,11 & 12,56 \\
\hline DD10 & \multirow{9}{*}{ 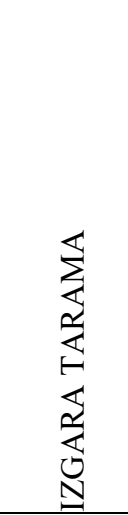 } & 140 & 1500 & 0,11 & 0,85 & 9,35 \\
\hline DD11 & & 150 & 1500 & 0,11 & 0,91 & 11,04 \\
\hline DD12 & & 170 & 1500 & 0,11 & 1,03 & 8,63 \\
\hline DD13 & & 190 & 1500 & 0,11 & 1,15 & 9,46 \\
\hline DD14 & & 160 & 1000 & 0,09 & 1,78 & 13,98 \\
\hline DD15 & & 160 & 1250 & 0,07 & 1,83 & 14,09 \\
\hline DD16 & & 170 & 1250 & 0,07 & 1,94 & 15,61 \\
\hline DD17 & & 180 & 1250 & 0,07 & 2,06 & 14,14 \\
\hline DD18 & & 190 & 1250 & 0,07 & 2,17 & 14,78 \\
\hline DD-EOS & & 170 & 1250 & 0,1 & 1,36 & 14,23 \\
\hline TAM DOLU & & 170 & 1250 & 0,1 & 1,36 & 22 \\
\hline $\begin{array}{l}\text { GELENEKSEL } \\
\text { İMALAT }\end{array}$ & & - & - & - & - & $17-22$ \\
\hline
\end{tabular}

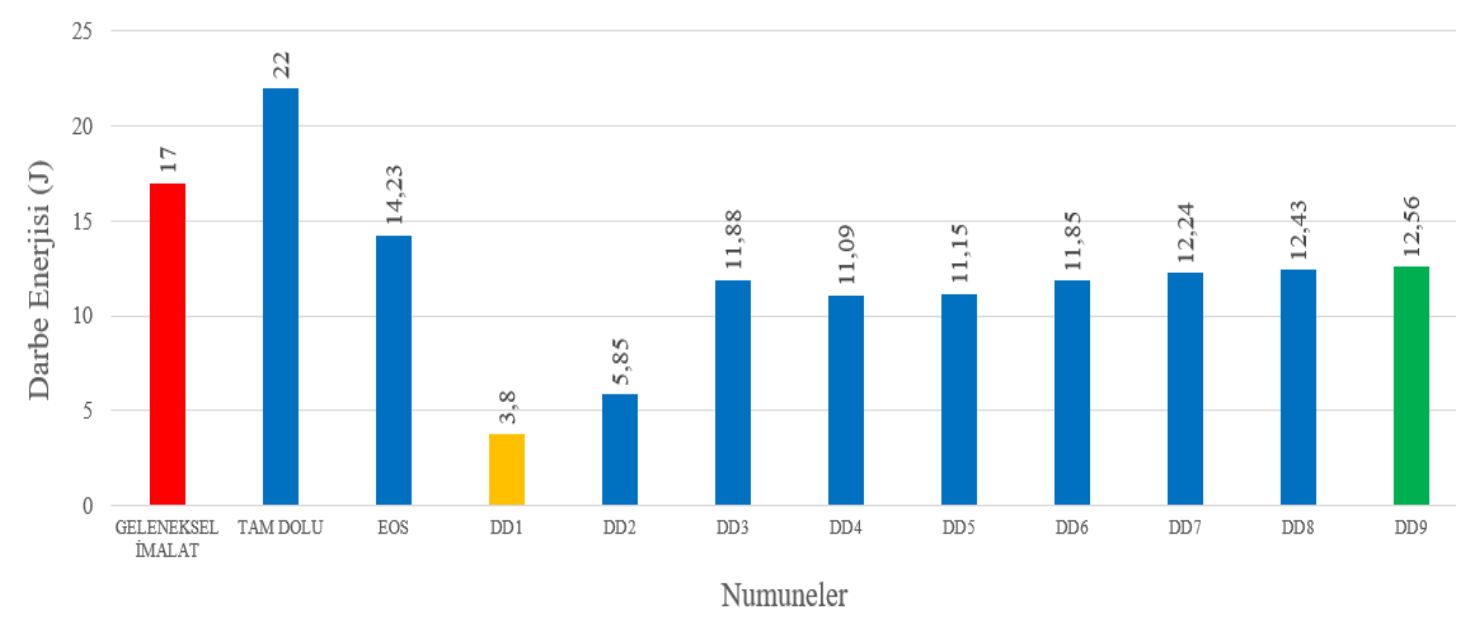

Şekil 17. Ada tarama stratejisiyle üretilen darbe numunelerinin test sonuçları (Charpy test results of the specimens produced with chess-rod type scanning strategy) 


\subsection{Mikro Sertlik Ölçümleri (Microhardness Measurements)}

Tablo 9'da numune gruplarının mikro sertlik ölçüm sonuçları verilmiştir. Tablo 9 incelendiğinde, en düşük enerji yoğunluğuna sahip parametrelerle üretilen numunelerin sertlik değerleri (SD3 numune grubunda 482 HV), geleneksel imalat yöntemleri ile üretilen Ti6Al4V alaşımı parçaların sertliğinden (291-337 HV) [33] ve daha yüksektir. Ancak bir malzemenin sert olması tüm mekanik özelliklerinin iyi olduğu anlamına gelmez. Özellikle darbe enerjisi düşer ve malzemenin kırılganlığ 1 artar. Şekil 19'da ada tarama ile üretilmiş numunelerin ortalama mikro sertlik değerleri verilmiştir. Şekil 19 incelendiğinde, ada tarama stratejisi ile üretilen SD3 numune grubunda en düşük sertlik değeri ve SD6 numune grubunda en yüksek sertlik değeri elde edilmiştir. Ada tarama stratejisinde enerji yoğunluğunun artmasıyla sertlik değerlerinin SD6 numune grubuna kadar arttığ1, daha sonra azaldığı görülmektedir. Şekil 20'de 1zgara tarama ile üretilmiş numunelerin ortalama mikro sertlik ölçüm değerleri verilmiştir. Grafikte, sertlik değerlerinin 1zgara tarama stratejisindeki farklı parametrelerden fazla etkilenmediği ve numuneler arasındaki sertlik farklılıklarının az olduğu görülmektedir. Izgara tarama stratejisiyle üretilen numunelerde en düşük sertlik değeri SD10 numune grubunda, en yüksek sertlik değeri ise SD13 numune grubunda elde edilmiştir.

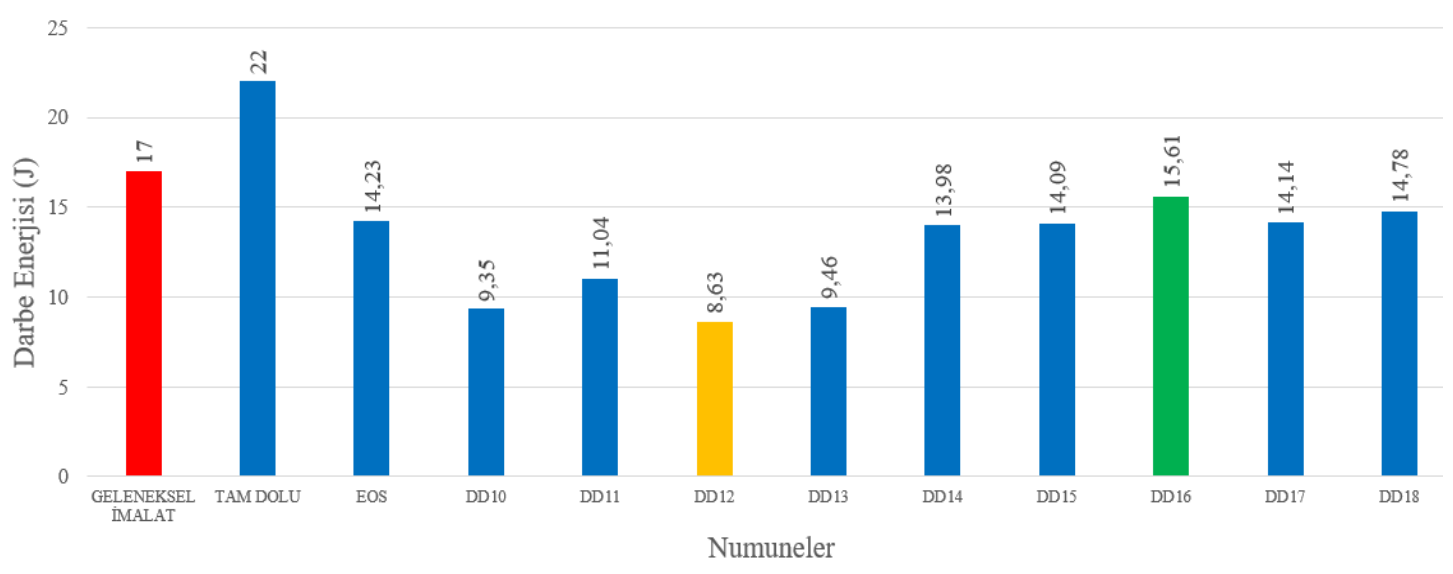

Şekil 18. Izgara tarama stratejisiyle üretilen darbe numunelerinin test sonuçları (Charpy test results of the specimens produced with grid type scanning strategy)

Tablo 9. Ada tarama ve 1zgara tarama stratejisiyle üretilmiş numunelerin ortalama mikro sertlik ölçüm sonuçları (Microhardness measurement results of the specimens produced with chess-rod type and grid type scanning strategy)

\begin{tabular}{|c|c|c|c|c|c|c|}
\hline Numune Grupları & $\begin{array}{l}\text { Tarama } \\
\text { Türü }\end{array}$ & $\begin{array}{l}\text { Lazer } \\
\text { Gücü } \\
(\mathrm{W})\end{array}$ & $\begin{array}{l}\text { Tarama H1z1 } \\
(\mathrm{mm} / \mathrm{sn})\end{array}$ & $\begin{array}{l}\text { Tarama } \\
\text { Mesafesi } \\
(\mathrm{mm})\end{array}$ & $\begin{array}{l}\text { Enerji } \\
\text { Yoğunluğu } \\
\left(\mathrm{J} / \mathrm{mm}^{2}\right)\end{array}$ & $\begin{array}{l}\text { Mikro } \\
\text { sertlik } \\
\text { Değeri } \\
(\mathrm{HV})\end{array}$ \\
\hline$\overline{\text { SD1 }}$ & & 160 & 1500 & 0,11 & 0,97 & 535 \\
\hline SD2 & & 180 & 1500 & 0,11 & 1,09 & 557 \\
\hline SD3 & & 140 & 1000 & 0,09 & 1,56 & 482 \\
\hline SD4 & $\$$ & 140 & 1250 & 0,07 & 1,60 & 570 \\
\hline SD5 & 夜 & 150 & 1000 & 0,09 & 1,67 & 573 \\
\hline SD6 & 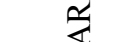 & 150 & 1250 & 0,07 & 1,71 & 601 \\
\hline SD7 & $\leftrightarrow$ & 170 & 1000 & 0,09 & 1,89 & 594 \\
\hline SD8 & $\varangle$ & 180 & 1000 & 0,09 & 2 & 586 \\
\hline SD9 & 8 & 190 & 1000 & 0,09 & 2,11 & 581 \\
\hline SD10 & & 140 & 1500 & 0,11 & 0,85 & 535 \\
\hline SD11 & $\varangle$ & 150 & 1500 & 0,11 & 0,91 & 547 \\
\hline SD12 & $\sum$ & 170 & 1500 & 0,11 & 1,03 & 542 \\
\hline SD13 & $\lesssim$ & 190 & 1500 & 0,11 & 1,15 & 556 \\
\hline SD14 & 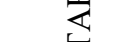 & 160 & 1000 & 0,09 & 1,78 & 548 \\
\hline SD15 & F & 160 & 1250 & 0,07 & 1,83 & 535 \\
\hline SD16 & $\gtrsim$ & 170 & 1250 & 0,07 & 1,94 & 537 \\
\hline SD17 & 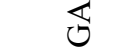 & 180 & 1250 & 0,07 & 2,06 & 539 \\
\hline SD18 & $\triangle$ & 190 & 1250 & 0,07 & 2,17 & 541 \\
\hline$\overline{\text { SD-EOS }}$ & & 170 & 1250 & 0,11 & 1,36 & 373 \\
\hline GELENEKSEL & & & & & & 291-337 \\
\hline İMALAT & & - & - & - & - & {$[33]$} \\
\hline
\end{tabular}




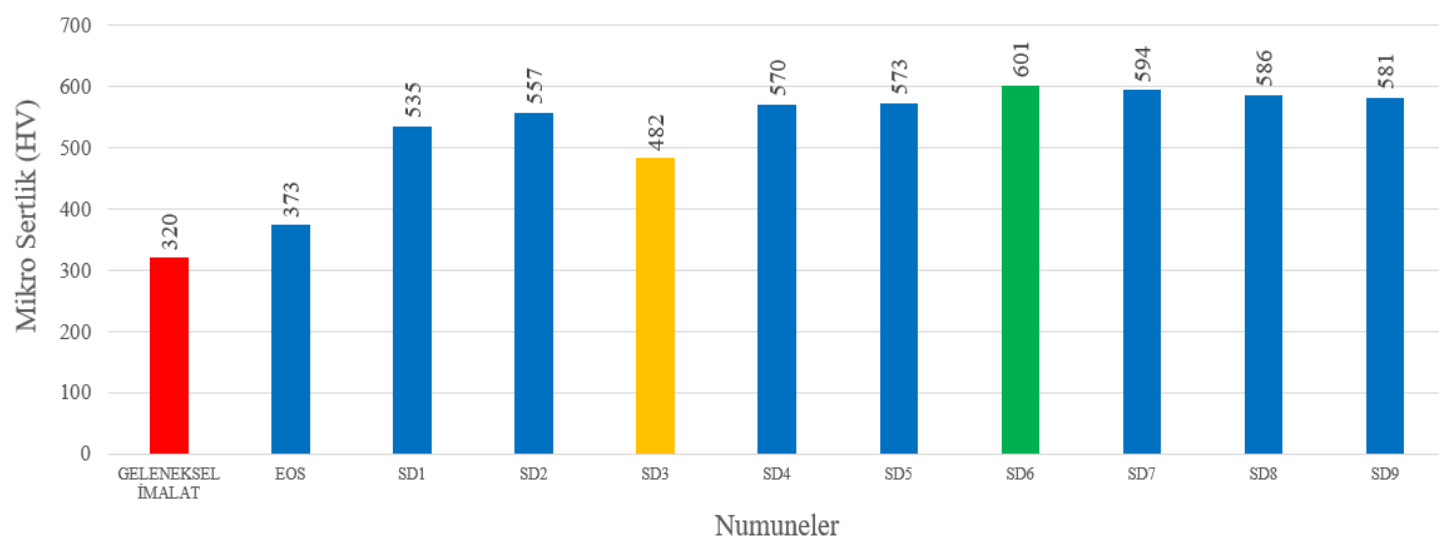

Şekil 19. Ada tarama ile üretilmiş numunelerin ortalama mikro sertlik değerleri (Microhardness values of the specimens produced with chess-rod type scanning strategy)

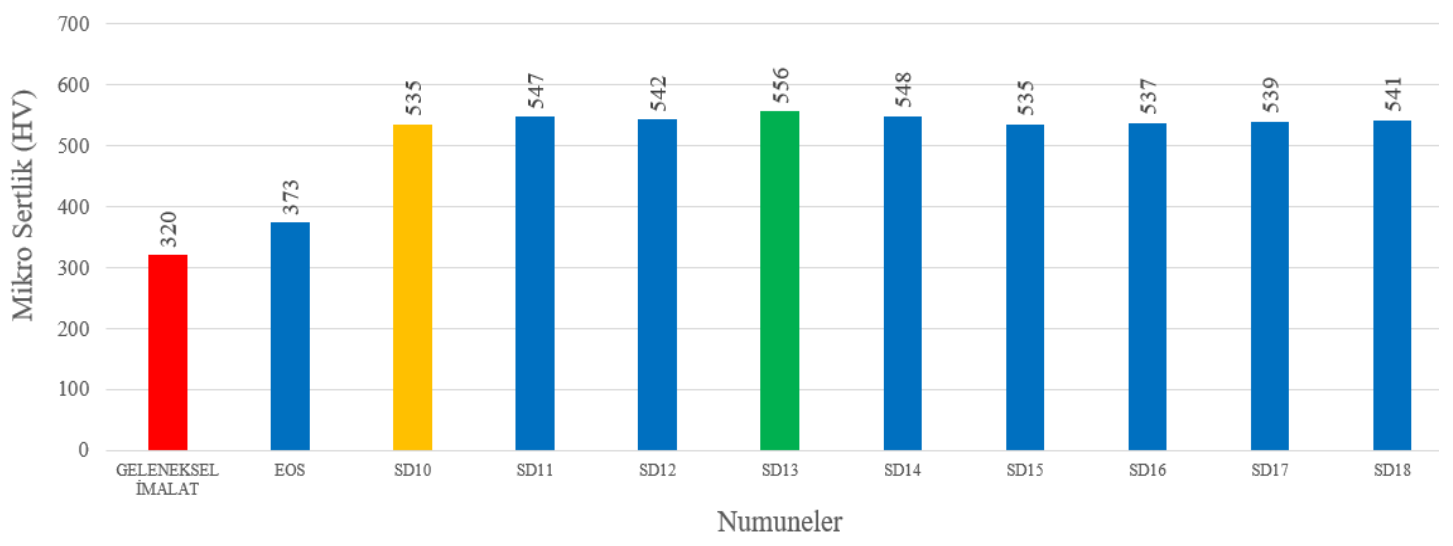

Şekil 20. Izgara tarama ile üretilmiş numunelerin ortalama mikro sertlik ölçüm değerleri (Microhardness values of the specimens produced with gridtype scanning strategy)

Sertlik değerleri, bu tarama stratejisinde de, belirli bir enerji yoğunluğuna kadar artmış, daha sonra düşüş göstermiştir. İmalatında lazer sinterlemenin kullanılacağı bir parçanın kullanım yerine göre beklenen dayanım değerlerini karşılayıp karşılamadığının belirlenebilmesi için, sadece sertlik değerlerine bakılması yanıltıcı olabilir. Mekanik deneylerde farklı parametreler ve farklı tarama stratejileri çok farklı sonuçlar verebilmektedir. Dolayısıyla, bir malzemeden beklenen dayanım değerlerini belirleyebilmek ve fikir edinebilmek açısından, o malzemenin farklı mekanik deney sonuçları birlikte değerlendirilmelidir.

\section{SONUÇLAR (CONCLUSIONS)}

$\mathrm{Bu}$ çalışmada, SLS cihazında farklı imalat parametreleri kullanılarak, Ti6A14V alaşımı geçişli (değişken) gözenekli deney numuneleri üretilerek mekanik özellikleri incelenmiştir. Dört faklı gözenek türü belirlenerek bir ön çalışma yapılmış, çekme testlerinden elde edilen en düşük elastisite modülüne sahip gözenek türü olan KRZ gözenek türü ile çalışmadaki deney numuneleri tasarlanmıştır. Numunelerin imalatında, enerji yoğunlukları 0,85 $\mathrm{J} / \mathrm{mm}^{2}$ ' den $2,17 \mathrm{~J} / \mathrm{mm}^{2}$,ye kadar değişen 18 farklı parametre belirlenerek, iki farklı tür tarama stratejisi kullanılmıştır. Mekanik deney sonuçlarına göre; en yüksek çekme dayanımı; lazer gücünün $190 \mathrm{~W}$, tarama hızının 1200 mm/sn, tarama mesafesinin $0,09 \mathrm{~mm}$ olduğu ve ada tarama stratejisinin kullanıldığı numune grubunda $346 \mathrm{MPa}$ elde edilmiştir. En yüksek basma dayanımı; lazer gücünün 160 $\mathrm{W}$, tarama hızının $1000 \mathrm{~mm} / \mathrm{sn}$, tarama mesafesinin 0,09 mm olduğu ve izgara tarama stratejisinin kullanıldığı numune grubunda $252 \mathrm{MPa}$ elde edilmiştir. En yüksek darbe enerjisi; lazer gücünün $170 \mathrm{~W}$, tarama hızının $1250 \mathrm{~mm} / \mathrm{sn}$, tarama mesafesinin $0,07 \mathrm{~mm}$ olduğu ve 1zgara tarama stratejisinin kullanıldığ1 numune grubunda 15,61 J elde edilmiştir. En yüksek mikro sertlik değeri; lazer gücünün $150 \mathrm{~W}$, tarama hızının $1250 \mathrm{~mm} / \mathrm{sn}$, tarama mesafesinin $0,07 \mathrm{~mm}$ olduğu ve ada tarama stratejisinin kullanıldığı numune grubunda 601 HV elde edilmiştir. Çekme, basma ve darbe testlerin en yüksek değerlerine 1zgara tarama stratejisiyle üretilen numune gruplarında rastlanmıştır. Ancak; lazer gücü, tarama hızı ve tarama mesafesinin bir fonksiyonu olan enerji yoğunluğu, lazerin enerjisini kullanarak üretim yapan seçici lazer sinterleme ve seçici lazer ergitme gibi imalat yöntemlerinde son ürünün dayanımını oldukça etkileyen bir faktördür. Dolayısıyla bu çalışmada elde edilen deney sonuçları; sonraki araştırmacılar için referans niteliğinde olup, imalatı yapılacak parçadan istenen farklı mekanik dayanım değerlerine göre imalat esnasında kullanılacak parametreler açısından fikir vermektedir. 


\section{TEŞEKKÜR (ACKNOWLEDGEMENT)}

Bu çalışma, TÜBİTAK tarafindan 113M169 kodlu proje ve SDÜ Bilimsel Araştırma Projeleri Koordinasyon Birimi tarafindan 3214-D2-12 nolu proje ile desteklenmiştir.

\section{KAYNAKLAR (REFERENCES)}

1. Enderle J.D., Blanchard M.S., Bronzino D.J., Biomaterials, Introduction to Biomedical Engineering, Academic Press, ABD, 220-222, 2012.

2. Nasab M.B., Hassan, M.R. Metallic Biomaterials of Knee and Hip - a review, Trends in Biomaterials and Artificial Organs, 24 (1), 69-82, 2010.

3. Walter M.J., Stainless Steel for Medical, (2006). http://www.veridiam.com/articles/article3.pdf. Yayın tarihi 2006. Erişim tarihi Mart 15, 2010.

4. Wang W., Ouyang Y., Poh C.K., Orthopaedic Implant Technology: Biomaterials fromPast to Future Review Article, Academy of Medicine, 40 (5), 237-244, 2011.

5. Oliveira M., Hussain N.S., Dias A.G., Lopes M.A., Azevedo L., Zenha H., et al., 3-D Biomodelling Technology for Maxillofacial Reconstruction, Material Scientific Engineering, 28,1347-51, 2008.

6. İşoğlu İ.A., v.d., Biyomalzemeler, Biyomedikal Mühendisliğinin Temelleri, Asyalı M.H., Nobel Yayınevi, Ankara, 1, 395-450, 2014.

7. Schmoelz W., Implant Materials in Spinal Surgery, Manual of Spine Surgery, SpringerHeidelberg, 17-21, 2012.

8. ASM International. Biomaterials in Orthopaedic Surgery.

http://www.asminternational.org/content/ASM/StoreFil es/05233G_Sample_Chapter.pdf. Yayın tarihi 2009. Erişim tarihi: Ocak 16, 2018.

9. Güven Ş.Y., Biyouyumluluk ve Biyomalzemelerin Seçimi, Süleyman Demirel Üniversitesi Mühendislik Bilimleri ve Tasarım Dergisi, 2 (3), Isparta, 303-311, 2014.

10. Niinomi M., Nakai M., Titanium-Based Biomaterials for Preventing Stress Shielding Between Implant Devices and Bone., International Journal of Biomaterials., 2011:836587.,doi:10.1155/2011/836587. 2011.

11. Taniguchi N., vd., Effect of Pore Size on Bone Ingrowth into Porous Titanium Implants Fabricated by Additive Manufacturing: An in vivo experiment, Materials Science and Engineering C, 59, 690-701, 2016.

12. Chen Q., Thouas G.A., Metallic Implant Biomaterials, Materials Science and Engineering R, 87, 1-57, 2015.

13. Parthasarathy J., 3D Modeling, Custom Implants and its Future Perspectives in Craniofacial Surgery. Ann. Maxillofac. Surg., 4, 9-18, 2014.

14. Van Bael S., vd., The Effect of Pore Geometry on the In Vitro Biological Behavior of Human Periosteumderived Cells Seeded on Selective Laser-Melted Ti6A14V Bone Scaffolds, Acta Biomaterialia, 8, 28242834, 2012.
15. Gao W., vd., The status, challenges, and future of additive manufacturing in engineering, ComputerAided Design, 69, 65-89, 2015.

16. Astm standard F2792-12a. Standard Terminology for Additive Manufacturing Technologies. http://www.astm.org/Standards/F2792.htm. Yayın tarihi: 2015. Erişim Tarihi: Ocak 16, 2018.

17. Song B., Dong S., Deng S., Liao H., Coddet C., Microstructure and Tensile Properties of Iron Parts Fabricated by Selective Laser Melting. Optics \& Laser Technology, 56, 451-460, 2014.

18. Data from EOS, Additive Manufacturing in the Medical Field, EOS. E-Manufacturing Solutions. http:// gpiprototype.com/images/PDF/EOS_Titanium_Ti64_e n.pdf. Yayın tarihi Kasım, 2011. Erişim tarihi Ocak 16, 2018.

19. Ivy I. Skeletal tissue. http://www.glogster.com /jen2092293/ skeletal-system/ g-6m2dfs8e6u1361 kaq4fqea0. Yayın tarihi 2005. Erişim tarihi Temmuz 2016.

20. Yusuf S.M., Gao N., Influence of Energy Density on Metallurgy and Properties in Metal Additive Manufacturing. Materials Science and Technology, 121, 2017.

21. Prashanth K.G., vd., Is The Energy Density a Reliable Parameter for Materials Synthesis by Selective Laser Melting?, Materials Research Letters. Taylor \& Francis, 5 (6), 386-390, 2017.

22. Alavi vd., Optimization of Process Parameters in MicroEDM of Ti-6Al-4V Based on Full Factorial Design. The International Journal of Advanced Manufacturing Technology,1-21, 2017.

23. Xuezhi vd., Parameter Optimization for Ti-47Al-2Cr$2 \mathrm{Nb}$ in Selective Laser Melting Based on Geometric Characteristics of Single Scan Tracks)., Optics \& Laser Technology, 90,71-79, 2017.

24. AlMangour B., Grzesiak D., Yang J. M., Effect Of Scanning Methods in The Selectıve Laser Melting Of 316L/TiC Nanocomposities, Solid Freeform Fabrication 2016: Proceedings of the 26th Annual International, 566-573, 2016.

25. EOS GmbH, Operation-EOSINT M 280/PSW3.6, 10.12, Almanya, 2012.

26. Song B., Dong S., Deng S., Liao H., Coddet C., Microstructure and Tensile Properties of Iron Parts Fabricated by Selective Laser Melting. Optics \& Laser Technology, 56, 451-460, 2014.

27. Yadroitsev I., Gusarov A., Yadroitsava I., Smurov I., Single Track Formation in Selective Laser Melting of Metal Powders. Journal of Materials Processing Technology, 210 (12), 1624-1631, 2010.

28. Kruth J.P., Levy G., Klocke F., Childs T.H.C., Consolidation Phenomena in Laser and Powder-Bed Based Layered Manufacturing. Annals of the CIRP, 56, 2, 730-759, 2007.

29. Gusarov A.V., Yadroitsev I., Bertrand Ph., Smurov I.I., Heat Transfer Modelling and Stability Analysis of Selective Laser Melting. ELSEVIER, Applied Surface Science, 254, 975-979, 2007. 
30. Murr L.E., vd., Characterization of Ti-6Al-4V Open Cellular Foams Fabricated by Additive Manufacturing Using Electron Beam Melting, Materials Science and Engineering A, 527, 1861-1868, 2010.

31. Puebla P., vd., Effect of Melt Scan Rate on Microstructure and Macrostructure for Electron Beam Melting of Ti-6Al-4V, Materials and Sciences and Applications, 3, 259-264, 2012.
32. MatWeb

Material

Property

Data. http://www.matweb.com/search/datasheet.aspx?MatG $\mathrm{UID}=\mathrm{c} 4297 \mathrm{fb} 8 \mathrm{f} 1094 \mathrm{da}$ 189732c224e3be1ed. Yay1n tarihi 2016. Erişim tarihi Temmuz 2016.

33. Kasperovich G., Hausmann J., Improvement of Fatigue Resistance and Ductility of TiAl6V4 Processed by Selective Laser Melting, Journal of Materials Processing Technology, 220, 202-214, 2015. 
